\title{
New genera records of split-eyed owlflies (Neuroptera: Myrmeleontidae: Ascalaphinae) from Colombia
}

\author{
Adrian Ardila-Camacho ${ }^{1,3}$; Jorge Ari Noriega ${ }^{2}$ \& Fernando Acevedo-Ramos ${ }^{1,4}$ \\ 1 Universidad Nacional Autónoma de México (UNAM), Instituto de Biología. México, D.F., México. \\ ${ }^{2}$ Universidad de los Andes (UNIANDES), Departamento de Ciencias Biológicas, Laboratorio de Zoología y Ecología Acuática (LAZOEA). \\ Bogotá, Colombia. ORCID: http://orcid.org/0000-0003-1760-7020. E-mail:jnorieg@hotmail.com \\ 3 ORCID: http://orcid.org/0000-0002-3750-8671. E-mail: aardilac88@gmail.com (corresponding author) \\ ${ }^{4}$ ORCID: http://orcid.org/0000-0001-7508-7807.E-mail: facevedoramos@gmail.com
}

\begin{abstract}
The genera Ameropterus Esben-Petersen, 1922 and Fillus Navás, 1919 are recorded from Colombia for the first time. New distributional records for two Cordulecerus Rambur, 1842 species are also presented. Ameropterus dissimilis (McLachlan, 1871) and Ameropterus scutellaris (Gerstaecker, 1894) are redescribed and illustrated, and Ameropterus mexicanus (Van der Weele, 1909) is here proposed as a junior synonym of the latter. The taxonomic status of Nephelasca crocea Navás, 1914 is discussed. Keys to the Colombian species of Ameropterus and Cordulecerus and a list of the split-eyed Ascalaphinae species of the New World are also given.
\end{abstract}

Key-Words. Neuropterida; Neotropics; Ascalaphini; Ululodini; Amazonia.

\section{INTRODUCTION}

The neuropteran families Ascalaphidae and Myrmeleontidae has been traditionally treated as closely related separated groups, and only recently were synonymized (Machado et al., 2019). Previous phylogenetic analyses recovered both families as monophyletic sister groups (Aspöck et al., 2001; Aspöck \& Aspöck, 2008; Badano et al., 2017; Michel et al., 2017). However, in recent studies Ascalaphidae was repeatedly recovered as paraphyletic (Winterton et al., 2010; Wang et al., 2017), and in a phylogenomic study of the Neuropterida, the group appeared forming two clades embedded within the Myrmeleontidae (Winterton et al., 2018). Traditionally, Ascalaphidae was divided into three subfamilies, Albardiinae with a single species, Ascalaphinae with 328 species, and Haplogleniinae with 95 species (Oswald \& Machado, 2018). Based on an estimation of the phylogenetic relationships of Myrmeleontoidea from a considerable taxon sampling of owlflies and antlions, and an alignment of 325 loci, both families were reciprocally recovered as paraphyletic, with the owlflies deeply nested within the antlions (Machado et al., 2019). Thus, a new classification of Myrmeleontidae where Ascalaphidae is treated as a subfamily was proposed. This subfamily comprises six tribes, namely
Dimarini (South America, Middle East, and Asia), Palparini (Afrotropical, Palearctic, and Oriental regions), Ululodini (Americas), Stilbopterygini (Australia), Haplogleniini (New World, Middle East, Afrotropical, and Oriental regions), and Ascalaphini (South America, Australia, Middle East, Palearctic, Afrotropical, and Oriental regions) (Machado et al., 2019). Currently, Ascalaphinae is composed by 127 genera and 596 species distributed in all biogeographical regions (Oswald \& Machado, 2018; Machado et al., 2019).

Members of the traditional Ascalaphidae are relatively uncommon, and often scarcely represented in collections. They are usually found in dry environments, plains, and wet forests. Morphologically, the owlflies are distinguished by having moderate to extremely elongated antennae terminating in an apical club; compound eyes are well developed, being either, hemispherical (e.g., Haplogleniini), or divided by a deep or shallow median sulcus (e.g., Ululodini and Ascalaphini); wings are elongated and narrow, with conspicuous pterostigma, and sometimes with colorful patterns; thorax is robust, while the legs are equipped with strong setae, tibial spurs, and tarsal claws (Tjeder, 1992). Larvae are generalist predators, distinguished by the presence of cordate posterior margin of head and presence of scolus-like processes on lateral sides of the body (Henry, 1976, 1977; Badano \& Pantaleoni, 2014). 
Neotropical fauna of Ascalaphidae (or Ascalaphinae sensu Machado et al., 2019) is scarcely studied, the taxonomy of the group has not been deeply addressed, and nearly all the groups need a comprehensive taxonomic work. The major taxonomic studies for this region are those of Van der Weele (1909), Navás (1912a, b), and Penny (1981a, b, 2002) but in general, genital characters and details of the external morphology are not available. Some taxonomic keys are based mainly in coloration characters, making the taxonomic identification unreliable (Navás, 1912a, b; Penny, 1981b, 2002). Of the Neotropical owlflies, the species richness is concentrated in the tribe Ululodini, a group endemic to the Americas (Table 1). According to Machado et al. (2019), Ululodini is divided into five genera, Albardia Van der Weele, 1903, Ameropterus Esben-Petersen, 1922, Ascalorphne Banks, 1915, Cordulecerus Rambur, 1842, and Ululodes Smith, 1900. Moreover, Ascalaphini contains two genera, Fillus Navás, 1919 and Nephelasca Navás, 1914 (Machado et al., 2019). Despite of that richness, the knowledge on the distribution and morphology is rudimentary. To Colombia, only four species of Ululodes, two of Cordulecerus, and one of Ascalaphini have been reported so far (Navás, 1914; Penny, 1977; Ardila-Camacho \& García-García, 2012; Oswald, 2018). The main purpose of the present study is to provide the first distributional records for the genera Ameropterus and Fillus in Colombia, as well as for some species of the genus Cordulecerus. Additionally, we discussed the taxonomic status of some genera and species, and redescribed $A$. dissimilis (McLachlan, 1871) and A. scutellaris (Gerstaecker, 1894).

\section{MATERIALS AND METHODS}

For the present study, specimens from the following entomological collections were studied:

ANDES-E Museo de Historia Natural, Universidad de los Andes - Bogotá, Colombia.

CAUD Colección de Artrópodos de la Universidad Distrital "Francisco José de Caldas" - Bogotá, Colombia.

IAvH Instituto de Investigación de Recursos Biológicos "Alexander von Humboldt" - Villa de Leyva, Colombia.

ICN Instituto Nacional de Ciencias Naturales, Universidad Nacional de Colombia - Bogotá, Colombia.

MPUJ Museo Javeriano de Historia Natural“Lorenzo Uribe", Pontificia Universidad Javeriana Bogotá, Colombia.

MUSENUV Museo Entomológico de la Universidad del Valle - Cali, Colombia.

The following international Museums are cited throughout the text.

BMNH Natural History Museum - London, England, United Kingdom.
CAS California Academy of Sciences - San Francisco, California, United States.

CNIN Colección Nacional de Insectos, Instituto de Biología, Universidad Nacional Autónoma de México - Mexico City, Mexico.

EMAU Ernst-Moritz-Arndt Universität, Zoologisches Institut and Museum - Greifswald, Mecklenburg-Vorpommern, Germany.

OUM Oxford University, Hope Entomological Collections - Oxford, England, United Kingdom.

MNCN Museo Nacional de Ciencias Naturales de Madrid - Madrid, Spain.

MCZ Museum of Comparative Zoology, Harvard University - Cambridge, Massachusetts, United States.

For the species identification, selected specimens were rehydrated, and their wings spread. External morphology was studied by means a Zeiss Discovery V8 stereomicroscope. High resolution photographs were taken with a ZEISS AxioZoom V16 microscope, and then were stacked using the ZENpro201 software. Images were processed using Adobe Photoshop CS6. For the study of the genital structures, the last four abdominal segments were dissected, and subsequently cleared in a hot solution of $10 \%$ Potassium Hydroxide $(\mathrm{KOH})$ for 15 minutes. Then, the cleared genitalia were washed as follows: a first wash with distilled water, a second wash with $10 \%$ acetic acid solution; a third wash with distilled water, and a final wash using $80 \%$ ethyl alcohol. Genitalia were preserved in glycerin and stored in a microvial pinned below the respective specimen. Morphological terminology of wing venation follows Breitkreuz et al. (2017), and genitalia morphology is based on Tjeder (1977).

\section{Taxonomy}

\section{Subfamily Ascalaphinae Lefèbvre, 1842 Tribe Ascalaphini Lefèbvre, 1842}

In the New World, the tribe Ascalaphini is represented by two genera: Fillus Navás, 1919, with three species, and Nephelasca Navás, 1914 with one (Table 1). Both genera were traditionally included within Suhpalacsini (Navás, 1914; Machado \& Rafael, 2011; Machado et al., 2019) which was created by Van der Weele (1909). The definition of Suhpalacsini is not well understood, and some authors considered them para- or polyphyletic (Tjeder \& Hansson, 1992; Michel \& Mansell, 2018). Such a tribe was separated from Ululodini because the presence of a well-developed fork of CuP on the hind wing, and a prominent process on the first abdominal segment of the males (Penny, 1981a). Suhpalacsini members were separated by the wing shape, relative lengths of foreand hind wings, and presence, form, and position of male tergal processes (New, 1984). Before this classification, Van der Weele (1909) described Acmonotus paradoxus based on a female specimen from Paraguay and placed 
Table 1. List of the New World split-eyed Ascalaphinae species.

\begin{tabular}{|c|c|c|c|}
\hline Tribe & Genus & Species & Geographical distribution \\
\hline \multirow[t]{63}{*}{ Ululodini Van der Weele, 1908} & \multirow[t]{4}{*}{ Ascalorphne Banks, 1915} & impavida (Walker, 1853) & Brazil \\
\hline & & leisewitzi (Navás, 1911) & Argentina, Paraguay \\
\hline & & macrocerca (Burmeister, 1839) & Brazil \\
\hline & & umbrina (Gerstaecker, 1894) & Bolivia, Paraguay \\
\hline & \multirow[t]{21}{*}{ Ameropterus Esben-Petersen, 1922} & breviantennis Penny, 1982 & Brazil, Costa Rica, Mexico, Panama \\
\hline & & consors (Gerstaecker, 1894) & Costa Rica, Panama \\
\hline & & delicatulus (McLachlan, 1871) & Brazil, Guyana \\
\hline & & dissimilis (McLachlan, 1871) & Brazil, Colombia, Peru, Suriname \\
\hline & & gallardoi (Navás, 1919) & Argentina \\
\hline & & integer (McLachlan, 1871) & Brazil \\
\hline & & karukerae (Lacroix, 1921) & Goadaloupe island \\
\hline & & longistigma (Navás, 1912) & Argentina \\
\hline & & misionarius (Williner, 1945) & Argentina \\
\hline & & mortoni Esben-Petersen, 1933 & Trinidad and Tobago \\
\hline & & muelleri (Van der Weele, 1909) & Brazil \\
\hline & & nigrostigma Navás, 1932 & Peru \\
\hline & & par (Navás, 1918) & Argentina \\
\hline & & peruvianus (Van der Weele, 1909) & Bolivia, Peru \\
\hline & & scutellaris (Gerstaecker, 1894) & Bolivia, Colombia, Costa Rica, Honduras, Mexico, Peru \\
\hline & & selysi (Van der Weele, 1909) & Brazil, Colombia, Venezuela \\
\hline & & sepultus (Walker, 1853) & Brazil \\
\hline & & subripiens (Walker, 1853) & Costa Rica, Panama, Venezuela \\
\hline & & trivialis (Gerstaecker, 1888) & Costa Rica, French Guiana, Guatemala, Mexico \\
\hline & & ululoides (Van der Weele, 1909) & Brazil \\
\hline & & versicolor (Burmeister, 1839) & Argentina, Brazil, Mexico \\
\hline & \multirow[t]{11}{*}{ Cordulecerus Rambur, 1842} & alopecinus (Burmeister, 1839) & Argentina, Brazil \\
\hline & & dohrni Van der Weele, 1909 & Ecuador \\
\hline & & elegans Van der Weele, 1909 & Brazil, Dominican Republic, French Guiana, Guyana, Suriname \\
\hline & & inquinatus Gerstaecker, 1888 & Costa Rica, Ecuador, Panama, Peru \\
\hline & & maclachlani Sélys-Longchamps, 1871 & Brazil, Suriname \\
\hline & & mexicanus Van der Weele, 1909 & Costa Rica, Mexico \\
\hline & & praecellens (Gerstaecker, 1885) & Colombia, Costa Rica, Ecuador, Panama, Venezuela, \\
\hline & & subiratus meridionalis Van der Weele, 1909 & Argentina, Brazil \\
\hline & & subiratus subiratus (Walker, 1853) & Brazil, Colombia, Costa Rica, Guatemala, Honduras, Mexico \\
\hline & & surinamensis (Fabricius, 1798) & Brazil, Colombia, Suriname \\
\hline & & unicus (Walker, 1860) & Brazil \\
\hline & \multirow[t]{27}{*}{ Ululodes Smith, 1900} & apollinaris Navás, 1927 & Colombia \\
\hline & & arizonensis Banks, 1907 & Mexico, USA \\
\hline & & banksiVan der Weele, 1909 & Haiti, Jamaica \\
\hline & & bicolor (Banks, 1895) & Costa Rica, French Guiane, Honduras, Mexico, Panama, USA \\
\hline & & brachycerus Navás, 1918 & Argentina, Ecuador \\
\hline & & cajennensis cajennensis (Fabricius, 1787) & $\begin{array}{l}\text { Argentina, Brazil, Costa Rica, Ecuador, French Guiana, Guatemala, Guyana, } \\
\text { Mexico, Paraguay, Peru, Saint Lucia, Suriname, Venezuela }\end{array}$ \\
\hline & & cajennensis nanus Navás, 1911 & Ecuador \\
\hline & & costanus Navás, 1914 & Brazil \\
\hline & & flavistigma Banks, 1908 & Ecuador \\
\hline & & floridanus (Banks, 1906) & USA \\
\hline & & heterocerus Navás, 1915 & Argentina \\
\hline & & macleayanus macleayanus (Guilding, 1825) & $\begin{array}{l}\text { Argentina, Brazil, Colombia, Costa Rica, Cuba, Haiti, Mexico, Saint Lucia, } \\
\text { Saint Vicent, USA, Venezuela }\end{array}$ \\
\hline & & macleayanus sanctaeluciae Van der Weele, 1909 & Saint Lucia \\
\hline & & mexicanus (McLachlan, 1871) & Mexico \\
\hline & & nigripes Banks, 1943 & USA \\
\hline & & oppositus Banks, 1938 & Puerto Rico \\
\hline & & pilosus Van der Weele, 1909 & Brazil \\
\hline & & quadripuctatus (Burmeister, 1839) & Canada, Mexico, USA \\
\hline & & roseni Navás, 1911 & Paraguay \\
\hline & & sanctidomingi Van der Weele, 1909 & Dominican Republic, Haiti \\
\hline & & sinuatus Banks, 1924 & Ecuador \\
\hline & & smithi Banks, 1938 & Haiti \\
\hline & & subvertens (Walker, 1853) & Argentina, Colombia, Haiti, Mexico, Venezuela \\
\hline & & tuberculatus (Banks, 1901) & Costa Rica, Mexico, Nicaragua \\
\hline & & vetulus (Rambur, 1842) & Argentina, Brazil, Paraguay \\
\hline & & villosus (Palisot de Beauvois, 1807) & Dominican Republic, French Guiana \\
\hline & & walkeri Van der Weele, 1909 & Cuba, Jamaica \\
\hline \multirow{3}{*}{ Tribe Ascalaphini Lefèbvre, 1842} & \multirow{3}{*}{ Fillus Navás, 1919} & amazonicus Machado \& Rafael, 2011 & Brazil \\
\hline & & brethesi Navás, 1919 & Argentina \\
\hline & & paradoxus (Van der Weele, 1909) & Paraguay \\
\hline
\end{tabular}


it within Acmonotini as the only representative of this group in the New World. Then, Navás (1914) proposed Nephelasca which was grouped within Suhpalacsini. In a further work, Navás (1919) erected Fillus from a male specimen from Argentina, and synonymized Acmonotini and Suhpalacsini, the author mentioned that Fillus has intermediate characteristics between Disparomitus Van der Weele, 1909 (Sub-saharian Africa and Yemen) and Acmonotus McLachlan, 1871 (Australia). Penny (1981a) revised the generic classification of the New World Ascalaphidae and indicates that because the tribe Suhpalacsini is defined from male characters, the tribal affiliation of Nephelasca remains uncertain.

\section{Genus Fillus Navás, 1919}

Fillus Navás, 1919, 17: 289. Type species Fillus brethesi Navás, 1919.

This genus is extremely rare in collections and known only from a few specimens. Recently, Machado \& Rafael (2011) described Fillus amazonicus from the Brazilian Amazon basin from two males and two females, providing detailed illustrations of abdominal characters of both sexes. Penny (1981a) and Machado \& Rafael (2011) point-
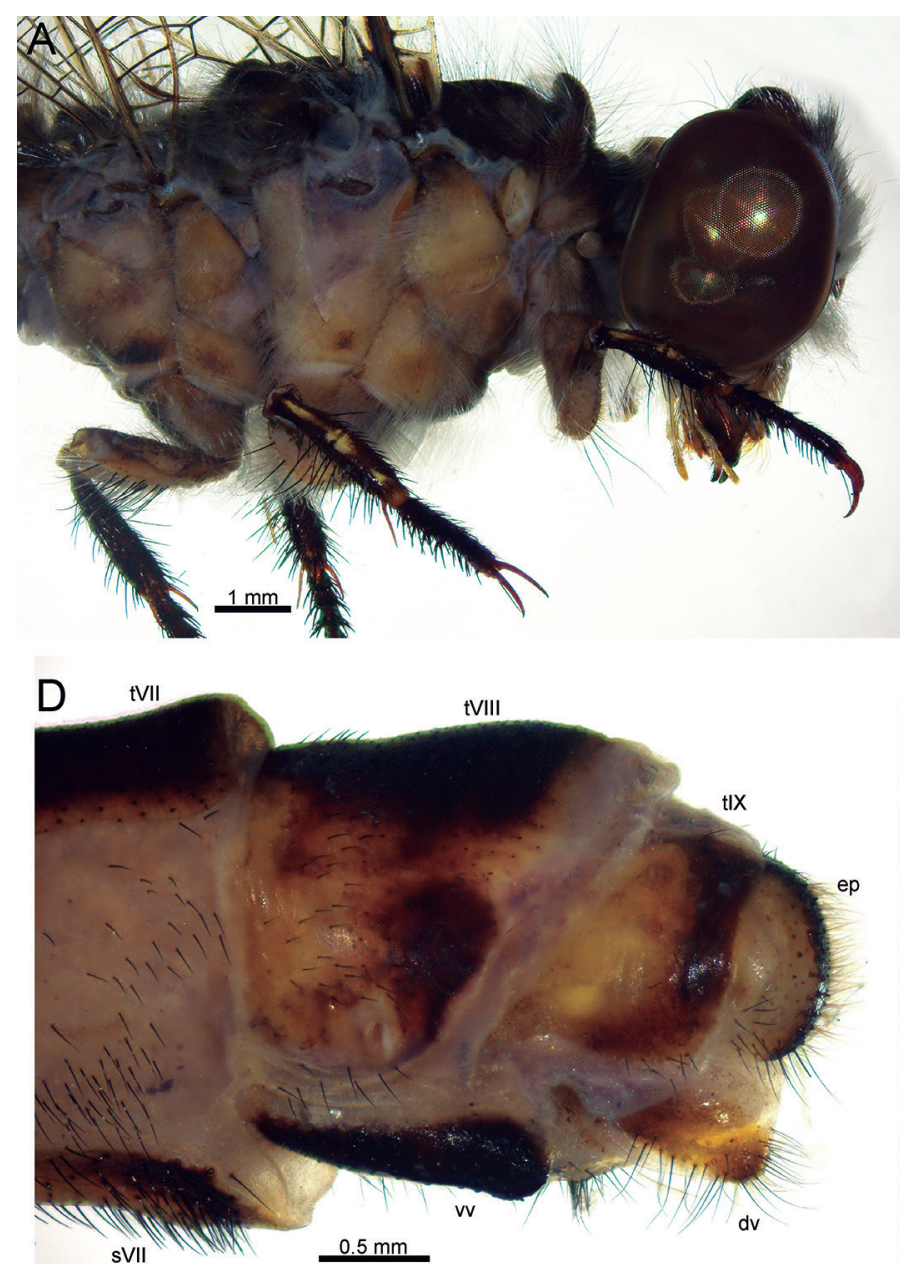

ed out that F. brethesi and F. paradoxus could represent the same species.

\section{Fillus sp. \\ (Fig. 1, 10)}

Specimen examined: Colombia: Meta: San Martín, Rey Zamuro, II-2012, J. Noriega, trampa de luz (1 \&-CAUD).

Comments: After the finding of a female specimen collected in the Colombian department of Meta, we concluded that it can confidentially be assigned to the genus Fillus. The specimen perfectly matches to the description and illustrations of Machado \& Rafael (2011), however because only a single female is available, we cannot assign this specimen to any of the known species.

The specimen reported herein presents short antennae with apical club piriform (Fig. 1C), similar to that of F. amazonicus; compound eyes have a shallow median depression (Fig. 1A), wings are hyaline with dark brown pterostigma; CuA on the hind wing is present, and the female genital sclerites (Figs. 1D, E) are similar to those illustrated by Machado \& Rafael (2011). It is probable that the Colombian specimen be the same described by Machado \& Rafael (2011), or alternatively a new species.
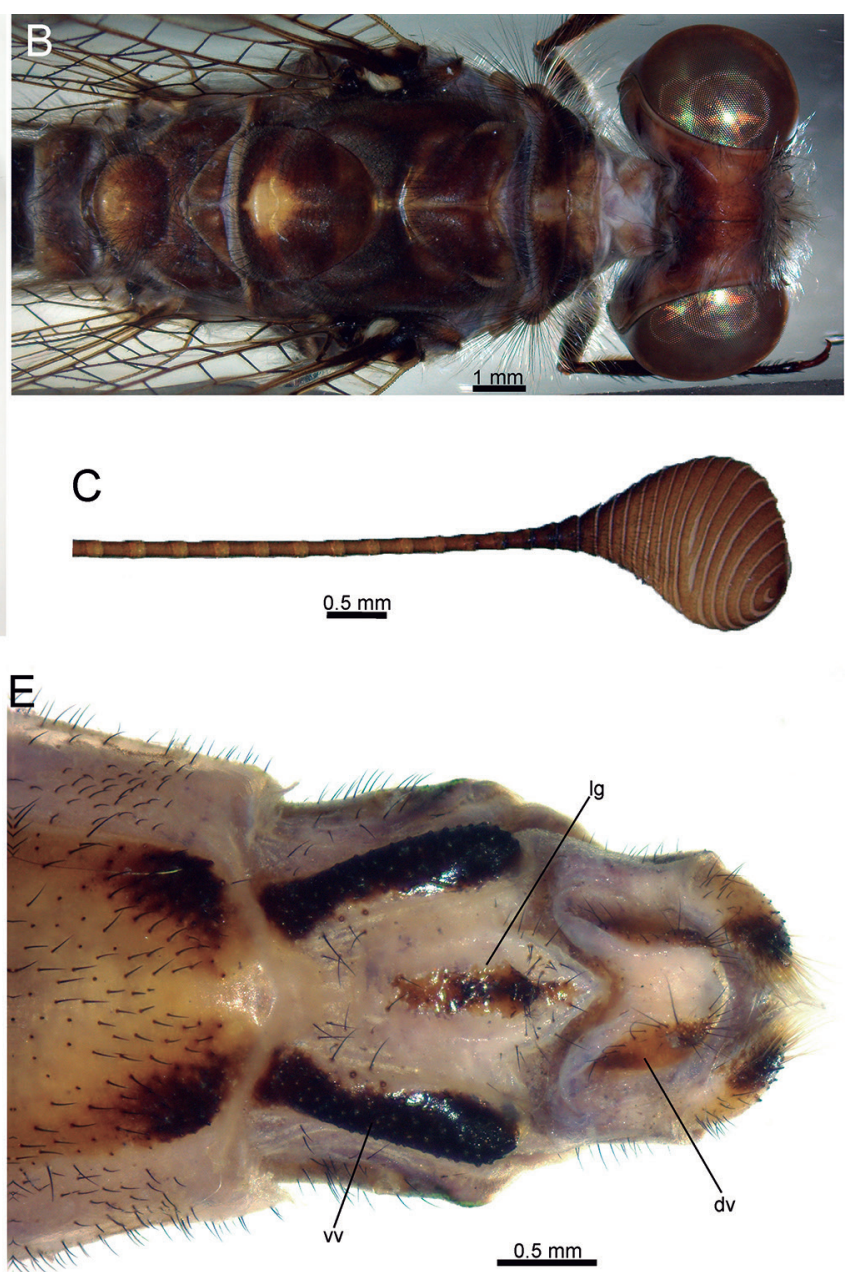

Figure 1. Fillus sp.: (A) head and thorax, lateral; (B) same, dorsal; (C) antennal apical club; (D) female terminalia, lateral; (E) same, ventral. Abbreviations: sVII, seventh sternite; $t V I I I-t I X$, tergites of abdominal segments VII-IX; ep, ectoproct; $d v$, distivalva; $v v$, ventrovalva; Ig, linguella. 


\section{Incertae sedis}

\section{Genus Nephelasca Navás, 1914 Nephelasca crocea Navás, 1914} (Fig. 2)

Nephelasca crocea Navás, 1914: 45. Holotype female. Type locality: Colombia (MNCN).

Remarks: This species was described by Navás (1914) from a single female specimen from Colombia, and was tentatively allied to Suhpalacsini. In a further publication Navás (1919) excluded Nephelasca from his key to Suhpalacsini genera without any explanation. Based on morphological resemblance of wing venation and color pattern Nephelasca seems to be closely related to the Old World genera Ascalaphus Fabricius, 1775 (Palearctic, Afrotropical, Oriental, Papua New Guinea) and Suhpalacsa Lefebvre, 1842 (Palearctic, Afrotropical, Oriental, Australia). Nowadays, this genus is included within Ascalaphini (Machado et al., 2019) however due to the morphological particularities mentioned above, primarily in the hind wing (Fig. $2 \mathrm{~A}$ ), this species could be included within some of the mentioned Old World genera. Alternatively, the species could belong to Ululodini because CuA of hind wing tends to be straight (Fig. 2A), a condition found in Ameropterus. In addition, the eye median sulcus is deep like in other Ululodini genera (Figs. 2B, C). By constrast, Fillus has the median sulcus of the compound eye shallow (Fig. 1A). Hence, this specimen was probably wrongly labeled, and due to these uncertainties on the tribal affiliation of this genus, we opted to consider N. crocea as incertae sedis. Consequently, Fillus becomes the only representative of the New World Ascalaphini.

\section{Tribe Ululodini Van der Weele, 1909 Genus Ameropterus Esben-Petersen, 1922}

Colobopterus Rambur, 1842: 360. Type species: Colobopterus leptocerus Rambur, 1842: 361. Ameropterus Esben-Petersen, 1922: 10: 621.

Ameropterus is a Neotropical genus with 21 species distributed from Mexico to Argentina (Penny, 2002) (Table 1). The validity of the genus has been questioned since some of their diagnostic traits are overlapped with those of a Nearctic Ululodes species (Penny, 2002). In the recent phylogenetic analysis of Machado et al. (2019), the

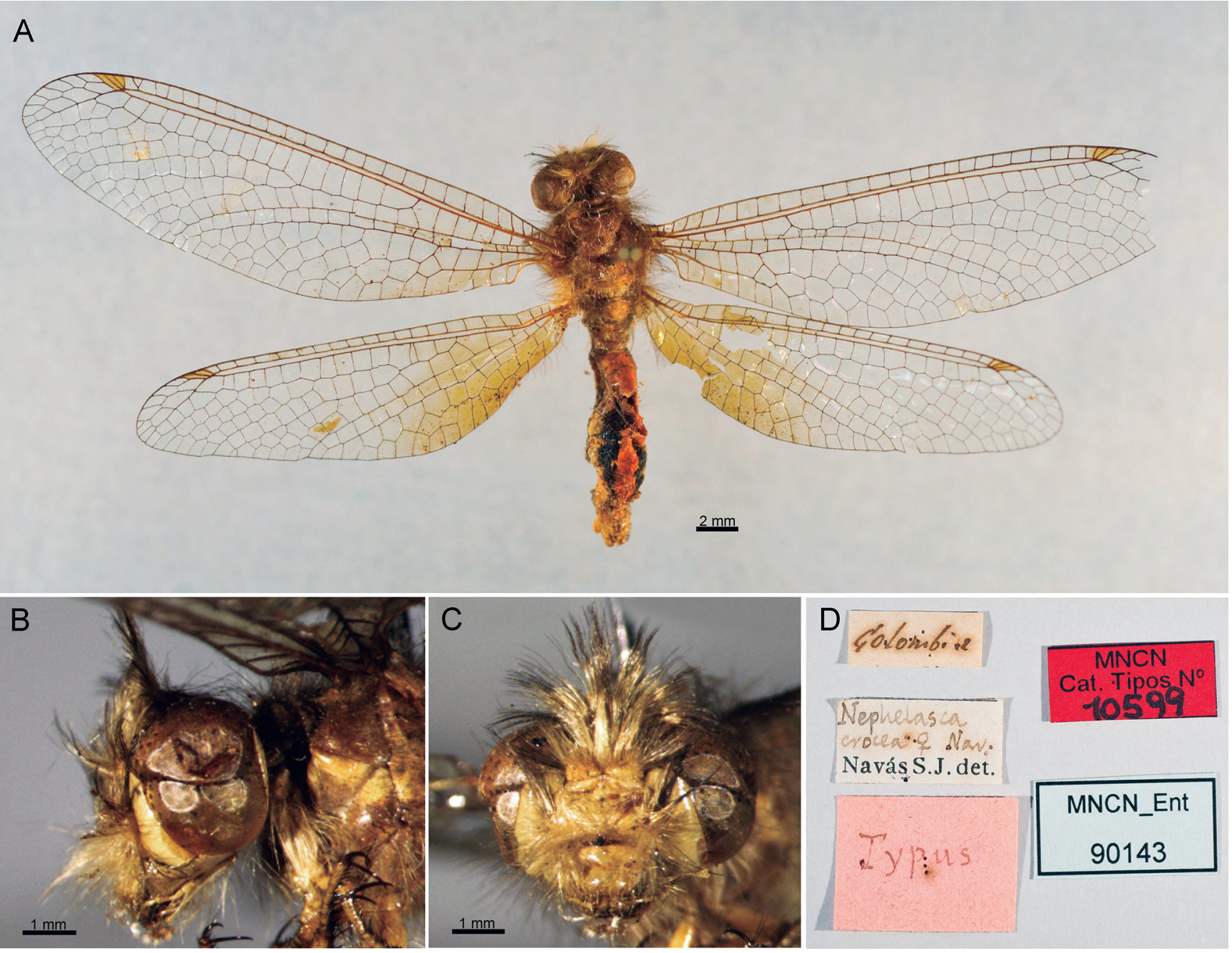

Figure 2. Nephelasca crocea Navás: (A) habitus of Holotype female, dorsal; (B) head, lateral; (C) same, frontal; (D) holotype labels. 
genus was recovered as paraphyletic. The group is distinguished by having wings elongated and narrow, sometimes with axillary angle of forewing moderately developed, and a distinct concavity on posterior wing margin plus an anal lobe on the hind wing. Antennal length is variable depending on the species, reaching laterally to level of forewing pterostigma or being longer than forewing. CuA (CuP sensu Penny, 2002) of hind wing is straight, whereas MA and MP are subparallel (Penny, 1981a, 2002). Male ectoproct is unmodified, lacking ventral clasper-like projections as in Ululodes (Shetlar, 1977). The genus has not been never reported in Colombia, but most of the species are known from neighboring countries. Species identification can be made with certain reliability following the works of Van der Weele (1909) and Penny (1981b). Heckman (2017) proposed a taxonomic key based on the works of Penny (1981a, b, 2002) and on the original descriptions and keys of Navás (1912a, 1919, 1932).

\section{Ameropterus scutellaris (Gerstaecker, 1894)}

(Figs. 3, 4, 10)

Colobopterus scutellaris Gerstaecker, 1894 [1893]: 109. Holotype sex unknown. Type locality: Huagamba, Peru (type depository unknown).

Ameropterus scutellaris (Gerstaecker, 1893). Penny, 1977: 10.

Colobopterus mexicanus Van der Weele, 1909: 122. Holotype male. Type locality: unknown (type depository unknown).

Ameropterus mexicanus (Van der Weele, 1909). Penny, 1977: 10. New synonym.

Specimens examined: Colombia: Antioquia: San Luís, Río Claro, 05.III.1994 (1 \&-MPUJ); Boyacá: Santa María, 04 $51^{\prime} 40^{\prime \prime} \mathrm{N}, 73^{\circ} 16^{\prime} 04^{\prime \prime} \mathrm{W}, 850 \mathrm{~m}, 25-\mathrm{IV}-2010$, A. Penagos, (1 ९-CAUD); same data but Sendero la Almenara,
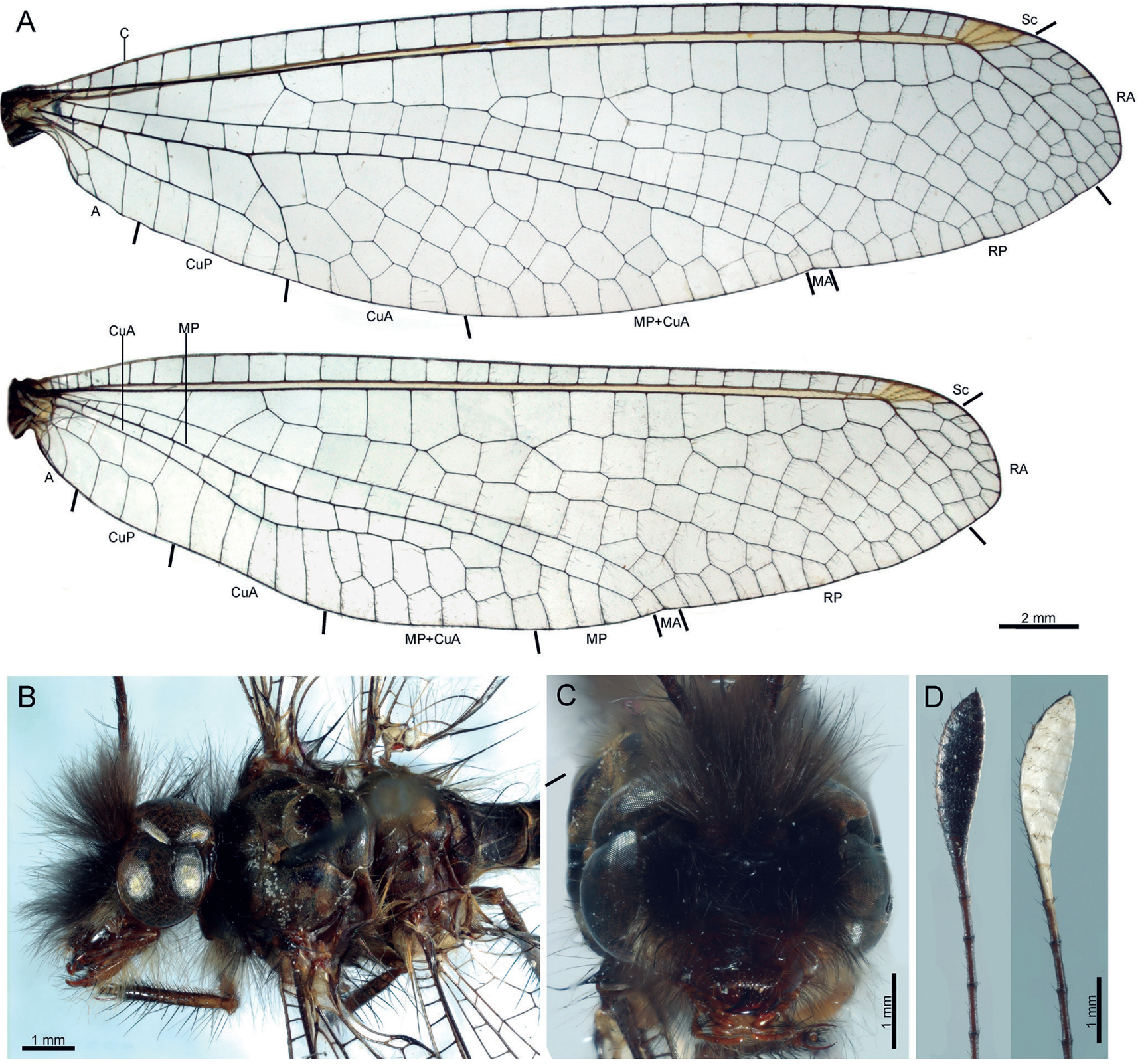

Figure 3. Ameropterus scutellaris: (A) wing venation; (B) head and thorax, dorsal; (C) head, frontal; (D) antennal apical club, ventral and dorsal surfaces, respectively. 
30-IV-2016, 13:00-14:00 hours, $04.87 \mathrm{~N}-73.25 \mathrm{~W}$, 1,168 m, D. Lozano (1 $\sigma^{2}$-CAUD); same data but Sendero la Almenara, 25-IV-2015, 04.87 N-73.25 W, 1,168 m, D. Lozano (1 $0^{\prime}$-CAUD); Cundinamarca: Nilo, Cerro Quininí, 0420'44.1"N, 74³0'43.1"W, 1,413 m, 07-VII-2019, A. Ardila \& J. Noriega leg. (1 \&-CAUD); Valle del Cauca: Restrepo, Campo Alegre, 1,100 m, 10-II-1984, D. Acosta, $\left(1 \sigma^{2}-\mathrm{ICN}\right)$.

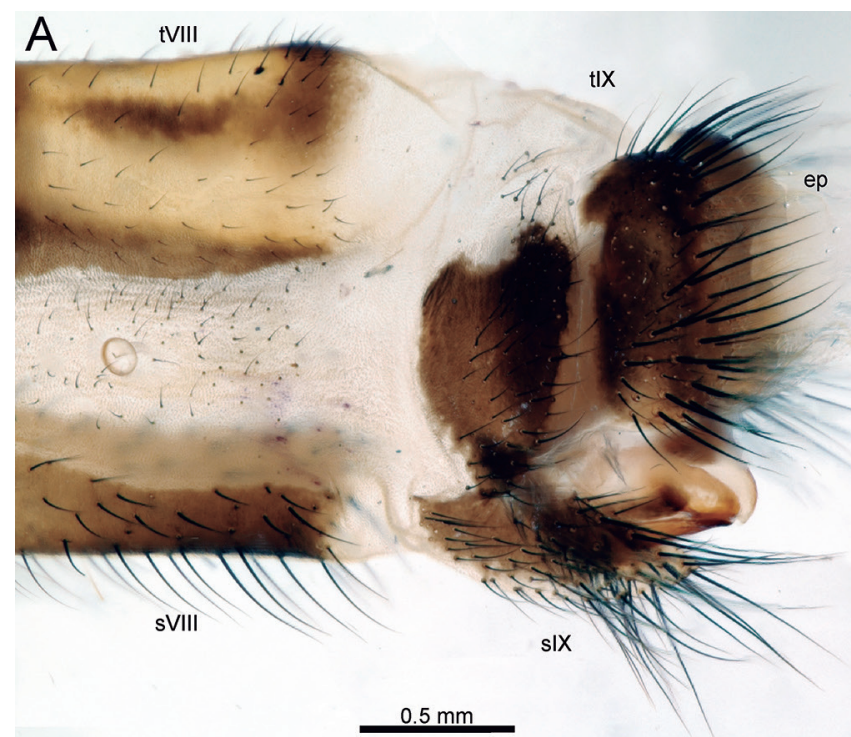

B
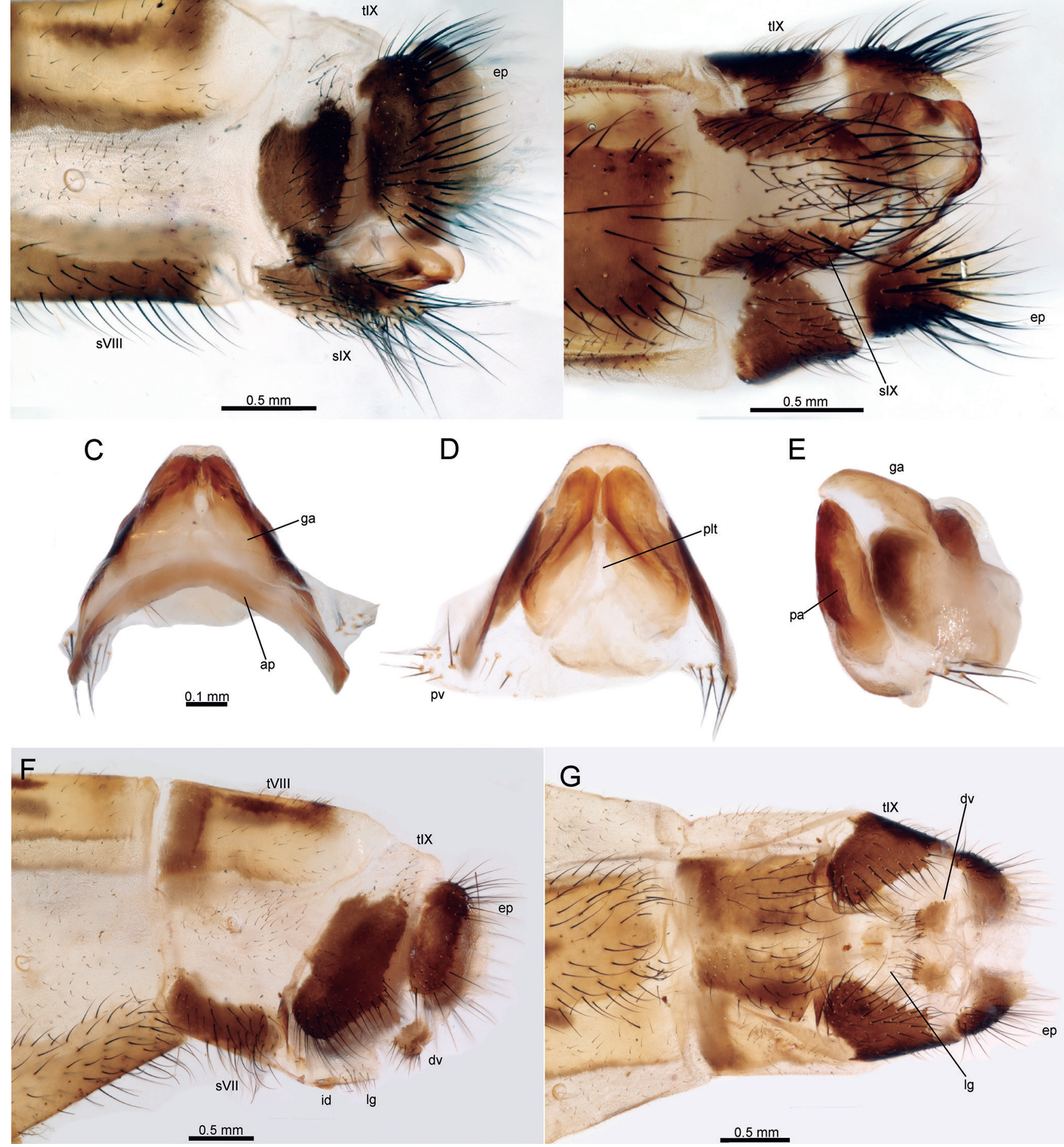

Figure 4. Ameropterus scutellaris: (A) male terminalia, lateral; (B) same, ventral; (C) male genitalia, dorsal; (D) same, ventral; (E) same, lateral; (F) female terminalia, lateral; (G) same, ventral. Abbreviations: Male: sVIII, sIX, sternites of abdominal segments VIII and IX; tVIII, tIX, tergites of abdominal segments VIII and IX; $e p$, ectoproct; ap, apodeme; ga, gonarcus; pa, parameres; plt, pelta; pV, pulvini. Female: sVII, seventh sternite; $t V I I I$, tIX, tergites of abdominal segments VIII and IX; $e p$, ectoproct; $d v$, distivalva; id, interdens; lg, linguella. 


\section{Redescription}

Measurements: interocular distance: $2.5-2.8 \mathrm{~mm}$; head width: 4.3-4.5 mm; antenna length: $30.6-31.1 \mathrm{~mm}$; body length: $23 \mathrm{~mm}$; forewing length: $27.0-28.8 \mathrm{~mm}$; forewing maximum width: $6.9-7.9 \mathrm{~mm}$; hind wing length: 24.2-25.9 $\mathrm{mm}$; hind wing maximum width: $6.3-7.2 \mathrm{~mm}$.

Head: Labrum subrectangular with lateral margins rounded, brown with fine brown setae; clypeus brown with lateral tufts of long, thin, dark brown setae; frons dark brown with abundant black or dark brown pilosity (Fig. 3C); gena dark brown with long, black or dark brown setae, whitish on the lower part of the gena; anterior part of vertex brown with dense tufts of dark brown setae; posterior portion of vertex brown, glabrous; occiput brown, glabrous; scape and pedicel brown with abundant long, interspersed dark brown and black setae; antennal flagellum with 42 flagellomeres including the apical knob, which is composed of nine flagellomeres; basal flagellomeres three or four times as long as wide, light brown, each article with abundant fine, long, dark brown setae and some scattered fine, short setae; remainder flagellomeres six times as long as wide, brown, covered with scattered, fine, short setae; apical club fusiform, white dorsally, dark brown ventrally with lateral, longitudinal whitish stripe (Fig. 3D), entire surface with minute dark brown setae. Mandibles brown with amber apex; maxillary palpi light brown (Fig. 3C), basal palpomere with long dark brown setae, remainder palpomeres with short, black setae; labial palpi light brown, the first palpomere with thick short setae, except apically with long, black setae, remainder palpomeres with minute, black setae. Compound eyes well developed, with deep median sulcus (Fig. 3B), brown in color.

Thorax: Prothorax brown, collar-like, covered with a dense layer of long brown setae. Mesonotum brown, entire surface with a layer of long, brown setae; metanotum brown with posterior region of scutellum light brown, setation as in mesonotum (Fig. 3B). Pteropleura brown with abundant light brown pilosity, some small portions on mesopleura with dark brown pilosity; ventral sclerites with dense light brown pilosity.

Legs: Fore coxa elongated, light brown; mid- and hind coxa light brown, all of them covered with abundant light brown pilosity. Trochanter light brown. Fore femur light brown, dorsally with fine long brown setae, ventrally with light brown setae; tibia light brown, dorsally with dark brown infuscations, entire surface with thick, long, dark brown bristles, and fine, short, dark brown setae; tibial spurs light amber, arched, as long as the first three tarsomeres together; tarsi brown, the first fourth with blackish apex, all of them covered with thick, short black setae, fifth tarsomere as long as the first four together. Tarsal claws light amber, shorter than tibial spurs. Mid femur brown, ventral surface with thick, long dark brown bristles, entire surface with minute, pale setae; tibia brown, entire surface with interspersed long and thick, and short and thick dark brown bristles; tibial spurs as in foreleg. Tarsi similar to those of foreleg. Hind femur elongated, brown with scattered, short, dark brown and fine pale setae, a few long dark brown bristles present; tibia light brown with dark brown infuscations, outer surface with short, fine, dark brown setae, inner surface with long, thick, dark brown bristles; tibial spurs elongated, and straight, light amber; tarsi brown, the first four with blackish apex, fifth tarsomere as long as the first four tarsomeres together, all of them covered with short and thick dark brown setae; pretarsal claws elongated, light amber.

Wings: Forewing elongated and narrow, membrane hyaline, venation brown, with minute dark brown setae; axillary angle obtuse (Fig. 3A). Costal area narrow, with 31-37 costal crossveins, those of the basal portion forming trapezoidal cells, remainder crossveins forming subquadrate cells. Pterostigma from pale to light brown (Fig. 3A), composed of four or five crossveins, apical area beyond pterostigma with three rows of cells. Subcostal space light amber. Area between $\mathrm{R}$ vein and MA before of fork of RP from RA with three crossveins. Area between RA and RP apically bent posteriorly below pterostigma, with 18-23 crossveins; RP with five branches. CuA fork located just before the level RP separation from RA. Area between CuA fork and posterior wing margin with six or seven rows of cells; $\mathrm{Cu}$ area with seven crossveins; CuP reaching the posterior wing margin at the level of RP origin from RA; area between CuP and posterior wing margin with five crossveins. Hind wing shorter than forewing, elongated and narrow, membrane hyaline, venation brown with minute dark brown setae; posterior wing margin with basal lobe not developed, and with a slight concavity at the CuA arch level, thus forming a sinuous area (Fig. 3A). Costal area narrow, slightly widened basally, with 31 or 32 crossveins, those at the basal portion forming trapezoidal cells, subquadrate cells on the basal widening and apex, remainder crossveins forming rectangular cells; pterostigma pale to light brown, composed of four crossveins; area beyond the pterostigma with two or three rows of cells. Area between $R$ vein and MA before RP forking from RA with single crossvein. Area between RA and RP apically bent posteriorly below pterostigma, with 16-19 crossveins. RP with five or six branches. Area between apex of CuA and posterior wing margin with two rows of cells; CuA reaching posterior wing margin beyond the origin of RP from RA level; CuP reaching the wing margin slightly beyond the wing base.

Abdomen: Shorter than forewings, tergite of abdominal segment II dark reddish brown, most of the surface with long black setae, except laterally light brown; tergites of abdominal segments III and IV black suffused with wide, lateral orange areas spots; tergites of abdominal segments V-VIII fuscous, with lateral, elongated, dark brown spot surrounded by a wide orange area on each side; all the tergites covered with short, dark brown setae. Sternite of abdominal segment II dark reddish brown with long, hair-like, light brown setae; remainder sternites dark reddish brown, entire surface covered with short, dark brown setae. 
Male genitalia: Ectoproct elongated, ovoid, densely covered with thick, long dark brown bristles, area adjacent to anal tubercle with fine, thin, pale setae (Fig. 4A). Tergite IX widened, ovoid, covered with short dark, brown setae. Sternite IX spoon-shaped in lateral view (Fig. 4A), apex reaching to slightly before the level of posterior margin of ectoproct; in ventral view elongated, U-shaped, area adjacent to posterior margins with thick, long dark brown bristles, entire surface with short dark brown setae (Fig. 4B). Paramere-gonarcus complex blunt in lateral view (Fig. 4E); gonarcus well sclerotized, anterior apodeme narrow, arched, lateral lobes slightly expanded, sub-quadrangular in lateral view; posterior apex blunt in dorsal view (Fig. 4C); parameres ovoid, pelta membranous (Fig. 4D).

Female genitalia: Ectoproct ovoid in lateral view (Fig.4F), distivalvae trapezoidal, mostly glabrous with a few short and fine setae on the ventral margin (Figs. 4F, G); linguella U-shaped in ventral view, semimembranous, covered by two lateral rows of fine and short setae (Fig. 4G).

Remarks: Ameropterus scutellaris and other three species, namely $A$. consors, $A$. mexicanus, and $A$. trivialis share a remarkable morphological resemblance. In fact, all of them were synonymized under $A$. trivialis by Shetlar (1977), although this work was not published, and these nomenclatural acts are not available. The wing venation and shape of the four species is nearly identical, unfortunately, these species are known only from old morphological descriptions, and other morphological traits such as genitalia are unknown (Van der Weele, 1909). Penny (2002) suggested that $A$. mexicanus could be synonymized with $A$. consors due to the scarce morphological differences and because both species have been collected in the same localities in Costa Rica. The range of geographical distribution of three species is largely overlapped, A. consors is known from Panama and Costa Rica, A. mexicanus has been reported from Mexico, Honduras, and Costa Rica, whereas A. trivialis is known from Mexico, Costa Rica, and Panama. For its part, A. scutellaris is known only from Bolivia and Peru (Van der Weele, 1909). The identification of our specimens was made based on the work of Van der Weele (1909), the examination of specimens deposited in CNIN, CAS, and MCZ. After the comparisons between specimens from Colombia and of A. mexicanus from CNIN and A. scutellaris from MCZ, no differences to separate them were found. We provide the present re-description to facilitate future comparisons and to help in the delimitation of these species. We also examined some photographs of $A$. consors and $A$. trivialis from Panama and Costa Rica, respectively, and we found only minor differences in wing shape and venation as well as color pattern of the thorax, although these specimens are also notably similar. A meticulous examination of the genitalia of specimens from different localities and molecular studies are necessary to clarify this problem.

Distribution: Mexico, Honduras, Costa Rica, Colombia, Bolivia, and Peru.

\section{Comparative material}

Ameropterus consors: Panama, Barro Colorado Island, Canal Zone, 28.VI.1986, R.G. Beard Leg. U.V. light (CAS).

Ameropterus trivialis: Costa Rica, Heredia, Chilamate EL., 100 m, 26.V.1990, m.v. light, D. Curoe Leg. (CAS).

Ameropterus mexicanus: Mexico, Chiapas, Tuxtla, 03.VI.1947, Det. P.A. Adams (CAS).

\section{Ameropterus dissimilis (McLachlan, 1871)}

(Figs. 5, 6, 10)

Colobopterus dissimilis McLachlan, 1871 [1873]: 251. "Amazonas, Bates, 1861, Colobopterus dissimilis det. McLachLan, o" (type)" (HOPE).

Ameropterus dissimilis (McLachlan, 1871). Penny, 1977: 10.

Specimens examined: Colombia, Amazonas, Leticia, Reserva Tanimboca, XII.2015, A. Aristizabal leg. (1 $\sigma^{2}$-CAUD).

Diagnosis: Median region of antennal flagellum distinctively curved; apical club ovoid, brown with median region cream coloured; forewing semitriangular, axillary angle slightly developed, followed by a wide concavity and a broadened lobe slightly beyond the origin of RP from RP level; hind wing narrow to semitriangular, posterior wing margin with basal lobe moderately developed, followed by a wide concavity and sometimes a moderate to well-developed lobe, slightly beyond the origin of RP from RA level when present. Area between $\mathrm{MP}$ and posterior wing margin beyond the apex of CuA with two rows of cells; sternite IX elongated, basal half subparallel-sided, distal half pentagonal, paramere-gonarcus complex acuminate in lateral view, gonarcus apex curved ventrad in lateral view.

\section{Redescription}

Measurements: interocular distance: $2.4 \mathrm{~mm}$; head width: $3.9 \mathrm{~mm}$; antenna length: $22.58 \mathrm{~mm}$; body length: $21.35 \mathrm{~mm}$; forewing length: 18.58-20.32 mm; forewing maximum width: 4.73-5.75 $\mathrm{mm}$; hind wing length: 16.73-17.25 $\mathrm{mm}$; hind wing maximum width: $3.26-4.38 \mathrm{~mm}$.

Head: Labrum narrow with anterior margin concave, lateral margins rounded, light brown with fine light brown setae; clypeus brown with lateral tufts of long, thin, interspersed pale and dark brown setae; frons brown with abundant brown pilosity; gena brown with interspersed long, pale, and dark brown setae (Fig. 5C); anterior part of vertex brown with dense tufts of interspersed pale, black, and dark brown setae; posterior portion of vertex, brown, glabrous; occiput bicolour (Fig. 5E), with light and dark brown, glabrous; scape and pedicel brown with abun- 

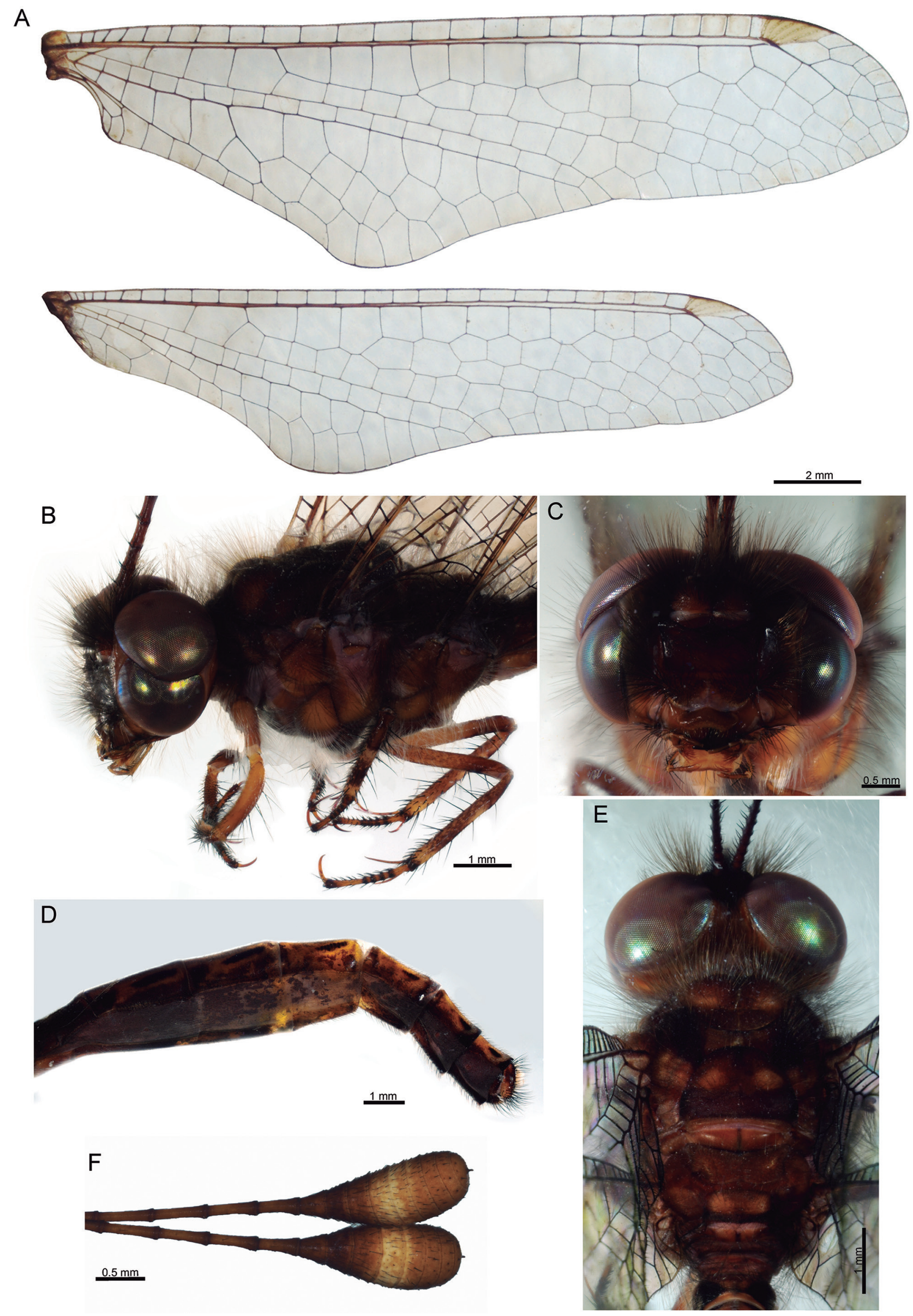

Figure 5. Ameropterus dissimilis: (A) wing venation; (B) head and thorax, lateral; (C) head, frontal; (D) abdomen, lateral; (E) head and thorax, dorsal; (F) antennal apical club. 
dant, long, interspersed brown and black setae (Fig. 5C); antennal flagellum with 44 flagellomeres including the apical knob, which is composed of nine flagellomeres; flagellomeres of basal half of antenna three or four times as long as wide, dark reddish brown, each article with two to four apical stout black bristles, remainder surface with scattered fine, short setae; median region of the flagellum distinctively curved; flagellomeres of distal half of flagellum, excluding apical knob, five times as long as wide, nearly glabrous, light brown. Apical club ovoid, with basal $1 / 3$ brown, median region cream coloured, and distal portion light brown (Fig. 5F); entire surface with minute dark brown setae. Mandibles brown with amber apex; maxillary palpi light brown, basal palpomere with long black setae, remainder palpomeres with short, black setae; labial palpi light brown, the first palpomere with thick short setae, except apically with long, black setae, remainder palpomeres with minute, black setae. Compound eyes well developed, with deep median sulcus (Fig. 5B), purplish.

Thorax: Prothorax brown, collar-like, covered with a dense layer of long dark brown or black setae. Mesonotum mostly brown, with lateral dark brown bands, posterior portion of scutellum dark brown, entire surface with a layer of long, brown setae; metanotum brown with posterior region of scutellum dark brown, setation as in mesonotum (Fig. 5E). Pteropleura brown with abundant brown pilosity, some small portions with whitish pilosity (Fig. 5B); ventral sclerites with dense white pilosity.

Legs: Fore coxa elongated, light brown; mid- and hind coxa brown, all of them covered with abundant white pilosity. Trochanter light brown. Fore femur light brown, dorsally with fine short pale setae, except at apex where are dark brown, ventrally with interspersed long, thin pale setae, and long, thick, dark brown setae; tibia brown, spotted with small light brown areas, entire surface with thick, long, dark brown bristles; tibial spurs light amber, arched, as long as the first four tarsomeres together; tarsi brown, covered with thick, short black setae, fifth tarsomere as long as the first four together. Tarsal claws light amber, as long as tibial spurs. Mid femur brown, ventral surface with thick, long dark brown bristles, entire surface with minute, pale setae; tibia with outer surface dashed with pale yellow and brown (Fig. 5B), inner surface light brown, entire surface with interspersed long and thick and short and thick dark brown bristles; tibial spurs as in foreleg. Tarsi similar to those of foreleg. Hind femur elongated, brown with scattered, minute dark brown setae and fine pale setae, a few long dark brown bristles present; tibia pale yellow with brown in-

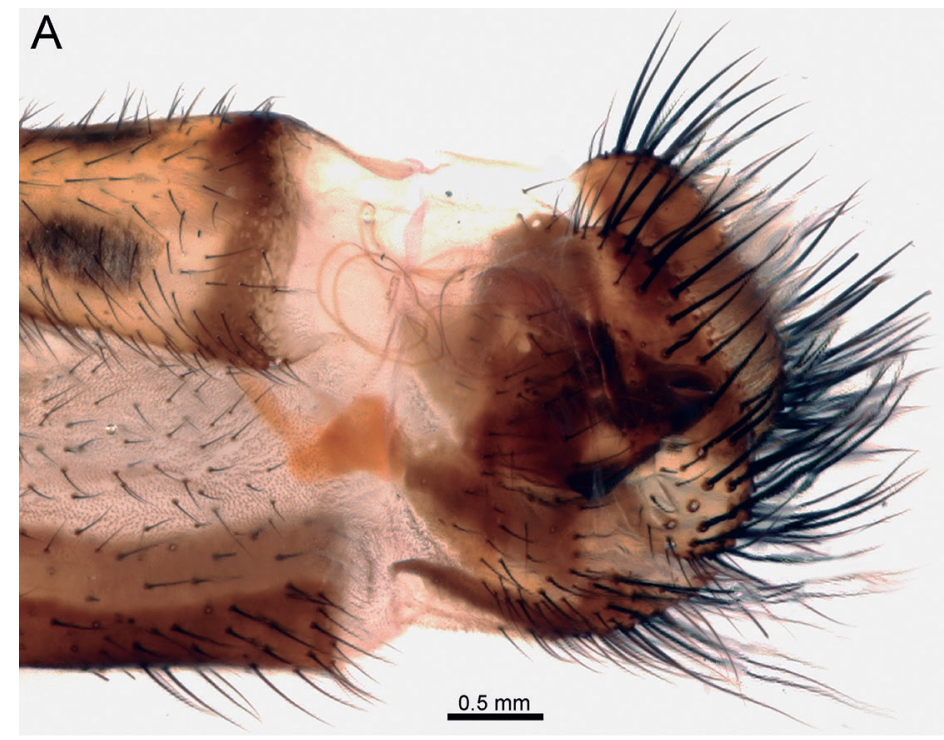

C

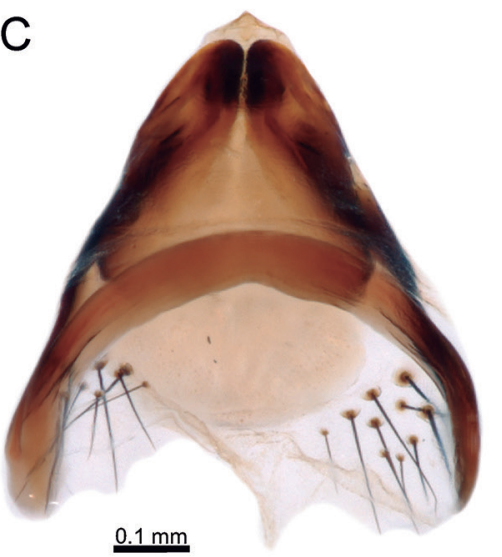

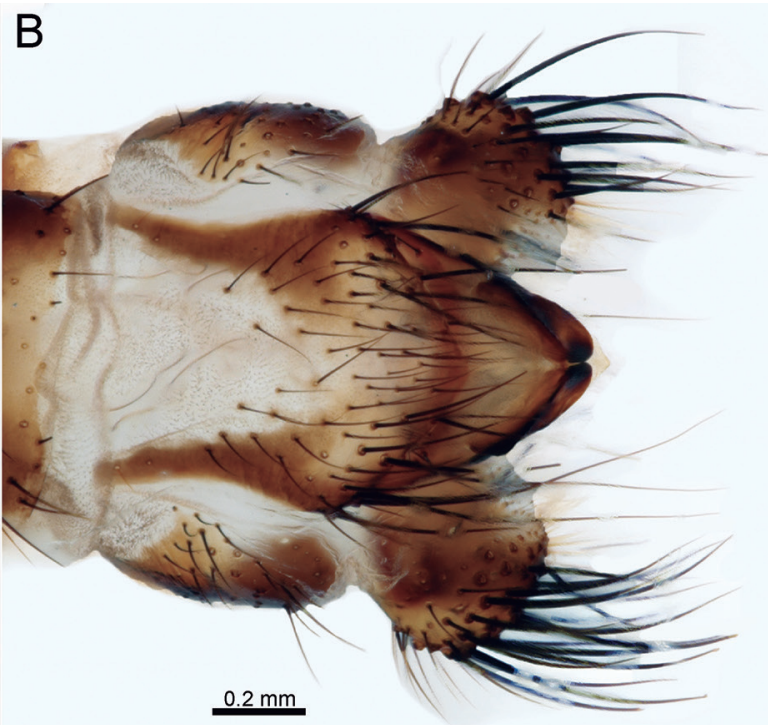

E
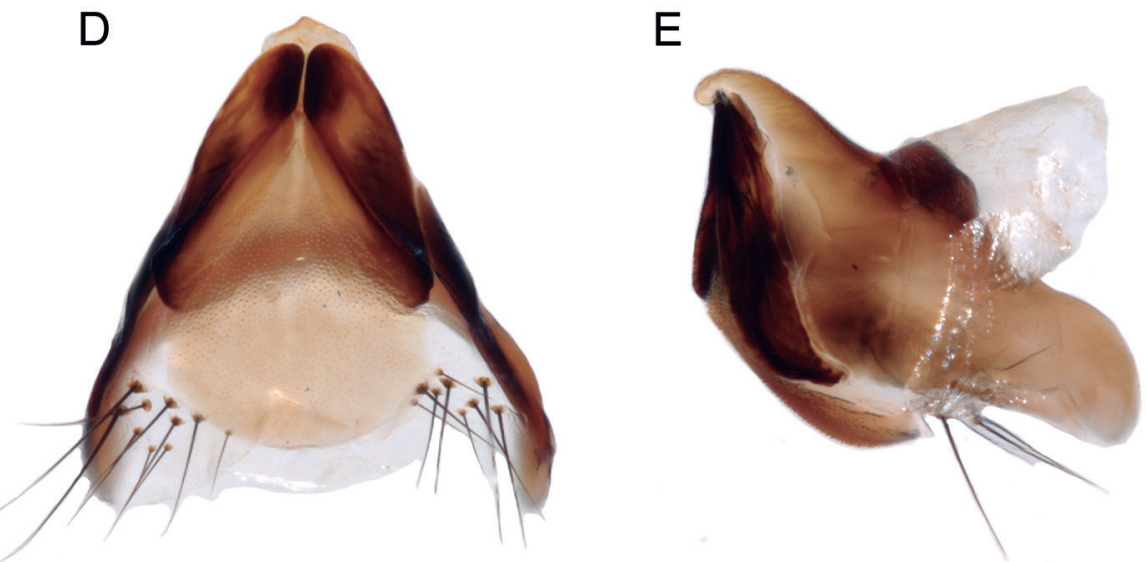

Figure 6. Ameropterus dissimilis: (A) male terminalia, lateral; (B) same, ventral; (C) male genitalia, dorsal; (D) same, ventral; (E) same, lateral. 
fuscations, apex dark brown, outer surface with short, fine, dark brown setae, inner surface with long, thick, dark brown bristles; tibial spurs elongated, and straight, light amber; tarsi brown with dark brown apical ring, first tarsomere as long as the second and third together, fifth tarsomere as long as the first four together, all of them covered with short and thick dark brown setae; pretarsal claws elongated, light amber.

Wings: Forewing semitriangular, membrane hyaline to light amber, venation brown, with minute dark brown setae; axillary angle somewhat developed, followed by a wide concavity and a broadened lobe slightly beyond the origin of RP from RP level (Fig. 5A). Costal area basally slightly widened, with 25 costal crosveins, those of the basal portion forming trapezoidal cells, and quadrate cells on the apex, remainder crossveins forming rectangular cells. Pterostigma pale, composed by five crossveins, apical area beyond pterostigma with two rows of cells. Area between $R$ vein and MA before of fork of RP from RA with three crossveins. Area between $\mathrm{RA}$ and RP apically bent posteriorly below pterostigma, with 14 crossveins; RP with four branches. CuA fork located just before the level RP separation from RA. Area between CuA fork and posterior wing margin with five rows of cells; $\mathrm{Cu}$ area with five crossveins; CuP reaching the posterior wing margin at the level of RP origin from $\mathrm{RA}$; area between CuP and posterior wing margin with five crossveins. Hind wing shorter than forewing, narrow to semitriangular, membrane hyaline to light amber, venation brown with minute dark brown setae; posterior wing margin with basal lobe moderately developed, followed by a wide concavity and sometimes by a moderate to well-developed lobe, slightly beyond the origin of RP from RA level when present (Fig. 5A). Costal area narrow, with 25 crossveins, those at the basal portion forming trapezoidal, remainder crossveins forming rectangular cells; pterostigma cream coloured, slightly light brown infuscated, composed of four crossveins; area beyond the pterostigma with two rows of cells. Area between $R$ vein and MA before of fork of RP from RA with single crossvein. Area between RA and RP apically bent posteriorly below pterostigma, with 13 crossveins. RP with five forks. Area between MP and posterior wing margin beyond the apex of CuA with two rows of cells; CuA reaching posterior wing margin beyond the origin of RP from RA level; CuP reaching the wing margin slightly beyond the wing base.

Abdomen: Shorter than forewings, tergite of abdominal segment II with lateral dark brown bands, light brown at middle, entire surface covered with dark brown setae; tergites of abdominal segments III and IV light brown with brown infuscations at margins, paired posterolateral, elongated dark brown spots (Fig. 5D), anterolateral corners with a dark brown spot on each side; tergites of abdominal segments V-VIII light brown, with brown infuscations on margins, posterolaterally with an elongated dark brown spot on each side; all the tergites covered with short, dark brown setae. Sternite of abdominal segment II light brown with long hair-like, pale setae; remainder sternites light brown with brown infuscations, entire surface covered with short, dark brown setae.

Male genitalia: Ectoproct elongated, ovoid, densely covered with thick, long dark brown bristles, area adjacent to anal tubercle with fine, thin, pale setae (Fig. 6A). Tergite IX posteroventrally rounded and covered with short dark, brown setae. Sternite IX spoon-shaped in lateral view, apex reaching to slightly before the level of posterior margin of ectoproct (Fig. 6A); in ventral view elongated, basal half subparallel-sided, distal half pentagonal, area adjacent to posterior margins with thick, long dark brown bristles, remainder surface with short dark brown setae (Fig. 6B). Paramere-gonarcus complex acuminate in lateral view, gonarcus apex distinctively curved ventrad in lateral view (Fig. 6E); gonarcus well sclerotized, arched, lateral arms expanded, narrow medially, posteriorly acuminate in dorsal view (Fig. 6C); parameres narrow, elongated, dark, pelta membranous, with minute spinulae (Fig. 6D).

Remarks: Ameropterus dissimilis presents remarkable morphological variation in hindwing shape and color. The wing membrane may vary from hyaline to light amber. The females have the hind wing generally narrower than males, however, there are also males with narrow hind wing. Some male specimens have the hind wing trianguloid, with one or two rows of cells on the area between MP and posterior wing margin beyond apex of CuA (Fig. 5A).

Distribution: Brazil, Colombia, Peru, and Suriname.

Comparative material: Brazil, Rondonia, Fazenda Rancho Grande, 62 km S. Ariquemes, 12 22.XI.1991, L.G. Bezark and D.E. Russell, Hg vapor light, Ameropterus dissimilis Det. Penny, 1992 (CAS); Rondonia, Faz. Rancho Grande, $62 \mathrm{~km} \mathrm{~S}$. Ariquemes, $10^{\circ} 32^{\prime} \mathrm{S}, 62^{\circ} 48^{\prime} \mathrm{W}$, 05 15.X.1993, C. and K. Messenger Leg. Ameropterus dissimilis Det. Penny, 1994 (CAS). Suriname, 10.IX.1942, Geijskes (1 o'-MCZ).

\section{Ameropterus selysi (Van der Weele, 1909) (Figs. 7, 8, 10)}

Colobopterus selysi Van der Weele, 1909: 134. Syntypes in multiple collections (Type locality: syntypes from Brazil, Honduras, and Venezuela).

Ameropterus selysi (Van der Weele, 1909). Penny, 1977: 10.

Specimens examined: Colombia: Guainía: Inírida, comunidad la ceiba, $03^{\circ} 37^{\prime} 58.7^{\prime \prime} \mathrm{N}, 67^{\circ} 53^{\prime} 22.1^{\prime \prime} \mathrm{W}$, 103 m, 25-III-2000, G. Galvis, (1 $\left.\sigma^{\top}-I C N\right)$; Magdalena: PNN Tayrona, $11^{\circ} 20^{\prime} \mathrm{N}, 74^{\circ} 02^{\prime} \mathrm{W}, 30 \mathrm{~m}, 17-29-I X-2001$, R. Henriquez, Malaise trap M.2135, (1 $\left.\sigma^{\prime \prime}-\mid A v H\right)$; Meta:

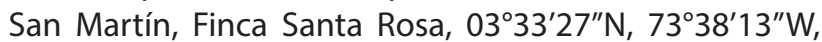
350 m, 11-XII-2006, A. Hurtado, N. Umaña, I. Medina, (1 \&-ANDES-E); Tolima, Prado, vda. El Tafurito, Reserva, 
Las Guacamayas, 04¹0'19.23"N, 74³7'36.58"W, 519 m, 04-V-2013, D. Rivera (1 9 -CAUD).

Diagnosis: Antennal club narrow, light brown (Fig. 7D); head and thorax mainly light brown (Figs. 7B, C); wings elongated and narrow, forewing with axillary angle moderately developed and followed by a strong concavity; hind wing basally constricted with a concavity, anal lobe moderately developed (Fig. 7A). Ectoproct ovoid in lateral view, posteroventrally with abundant thick and long setae (Fig. 8A); sternite IX narrow, spoon-shaped in lateral view (Fig. $8 \mathrm{~A}$ ), in ventral view with distal half view nearly subpentagonal with angles rounded (Fig. 8B); lateral lobes of gonarcus rounded, posterior apex slightly curved ventrally (Fig. 8E).

Remarks: Morphologically $A$. selysi resembles $A$. subripiens and $A$. versicolor, however hind wing is narrower with the anal lobe less developed. This species is reported to Colombia for the first time. The new records are from Tayrona Natural Park, Magdalena, locality found in the Caribbean coast of the country, and Guainía, a local- ity found near the eastern boundary with Venezuela in the Amazonian region of Colombia. Other records are from San Martín, Meta in the plains of the Colombian Orinoquia, contiguous to the eastern slope of the eastern cordillera, and from Tolima, which is found in the Magdalena river basin.

Distribution: Colombia, Venezuela, and Brazil.

\section{Key to Colombian species of Ameropterus}

1 Hind wing ovoid, similar in shape to forewing, posterior margin convex or with subtle concavity below CuA arch (CuP sensu Penny, 2002) (Fig. 3A)

A. scutellaris

1'Hind wing narrower than forewing, posterior margin with a concavity on basal $1 / 3$

2 Fore wing trianguloid with a prominent lobe on posterior wing margin just after the level of separation of RP from RA; hind wing base not so narrowed and without an axillary lobe (Fig. 5A) ................. A. dissimilis

2' Fore- and hind wing narrow, sub-parallel sided in most of their extension; hind wing base narrowed and with an axillary lobe (Fig. 7A)...A. selysi
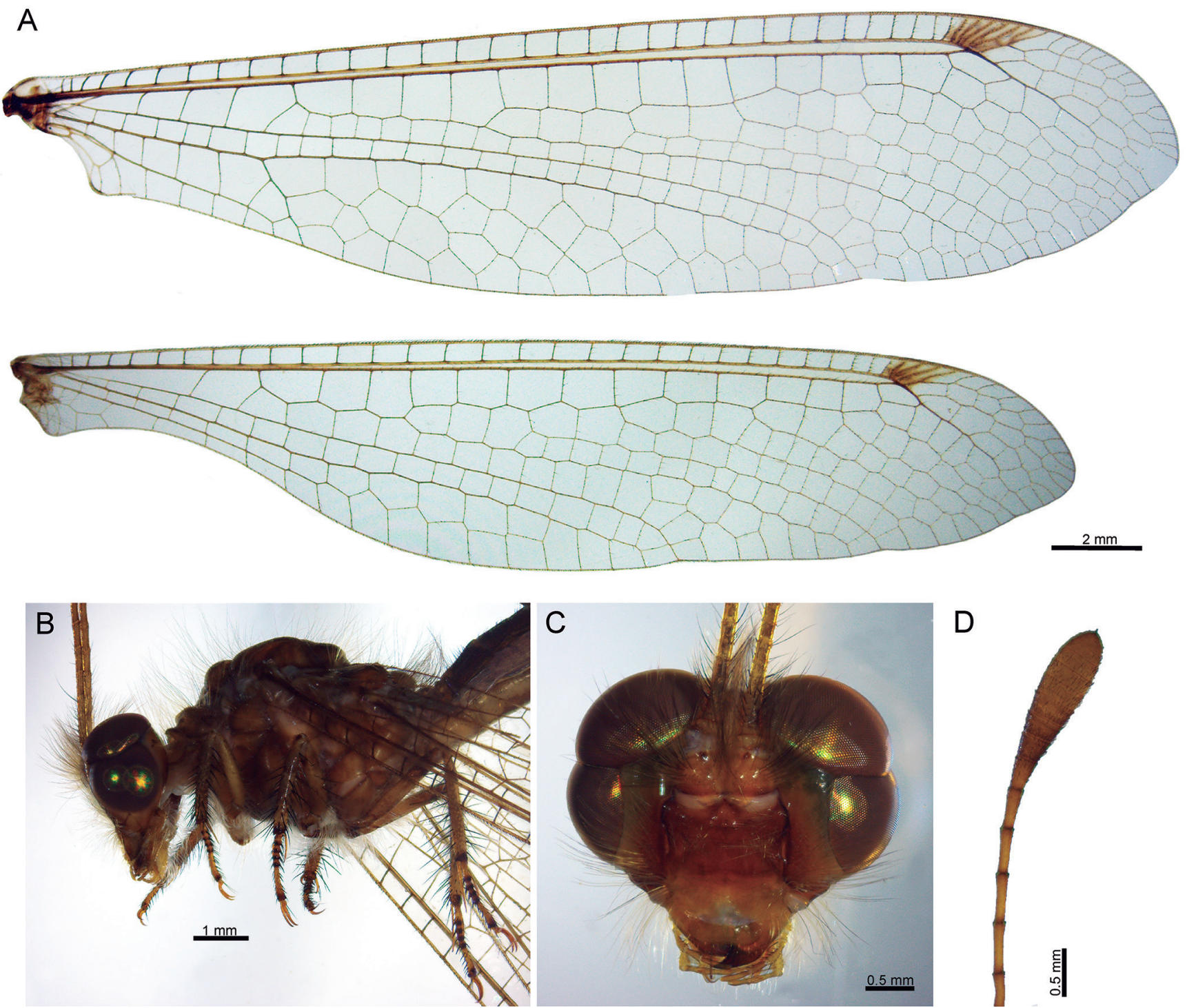

D

Figure 7. Ameropterus selysi: (A) wing venation; (B) head and thorax, lateral; (C) head, frontal; (D) antennal apical club. 


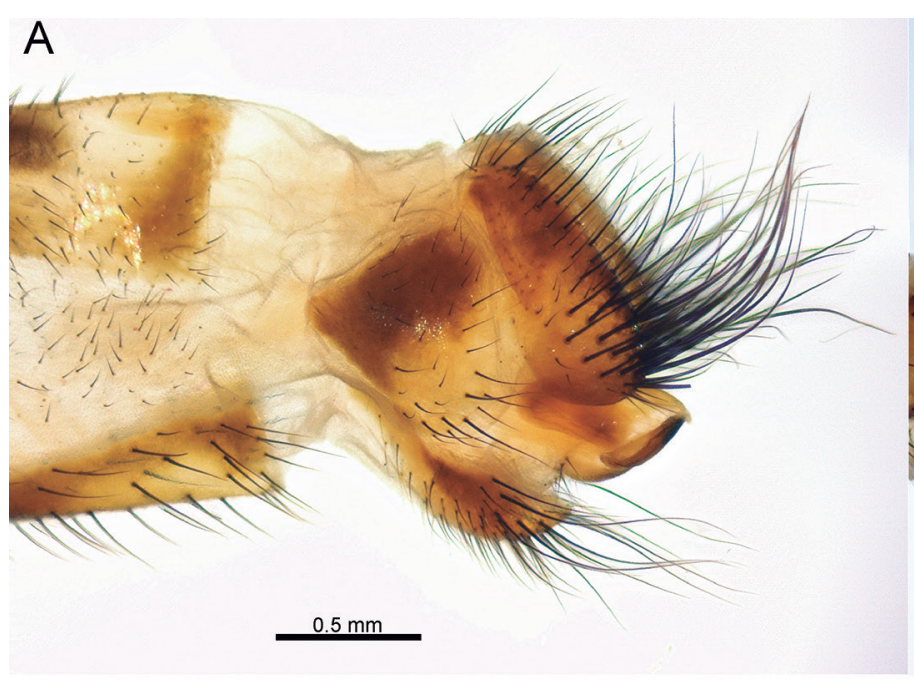

C

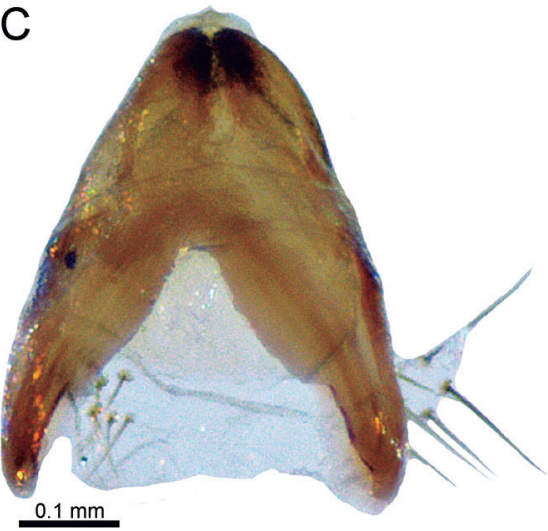

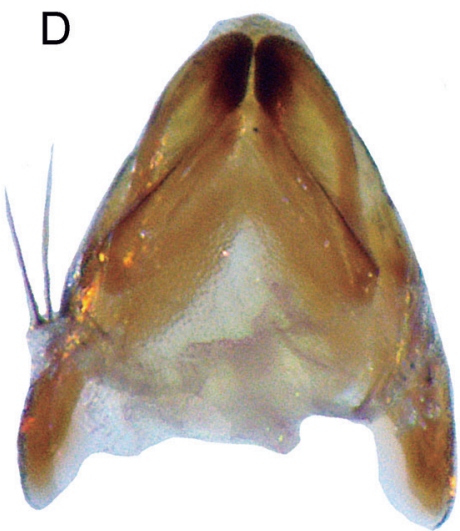

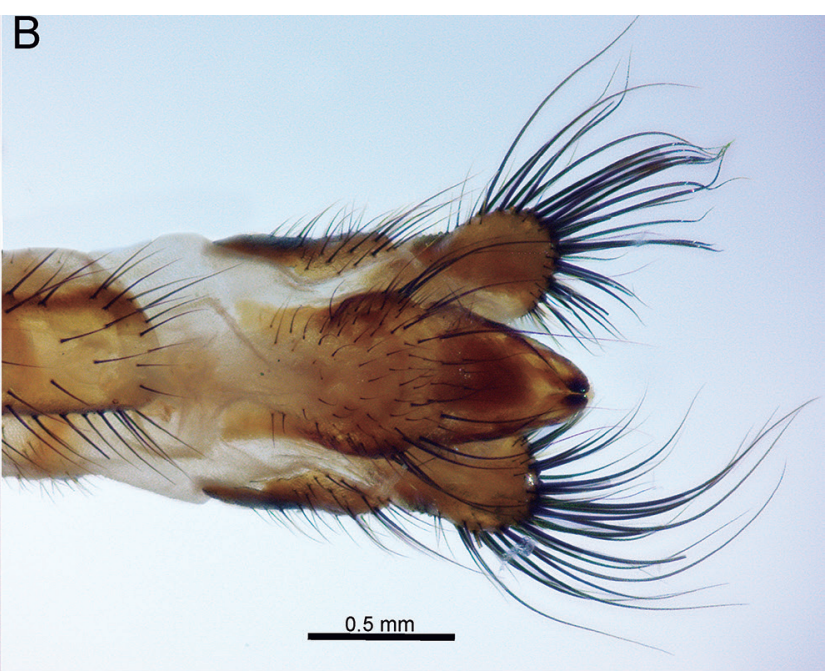

E

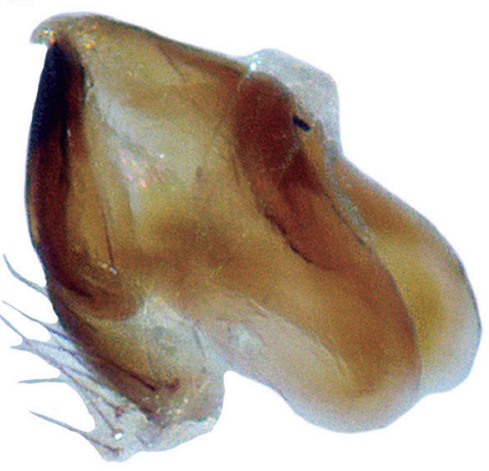

Figure 8. Ameropterus selysi: (A) male terminalia, lateral; (B) same, ventral; (C) male genitalia, dorsal; (D) same, ventral; (E) same, lateral.

\section{Genus Cordulecerus Rambur, 1842}

Cordulecerus Rambur, 1842: 359. Type species: Ascalaphus surinamensis Fabricius, 1798: 207.

This genus is exclusively Neotropical and with a distribution range from Mexico to Argentina (Van der Weele, 1909; Penny, 1981a). The group includes 10 species and one subspecies (Table 1), which in general are easily distinguished by a trianguloid shape of the hind wing often with distinct dark maculation (Penny, 1981a). Species of this genus may be identified following the keys of Penny (1981b, 2002) and Heckman (2017), and the monograph of Van der Weele (1909). Some species are likely mimics of vespid wasps, due to the shape and dashed color pattern of the abdomen (Henry, 1977). To Colombia C. praecellens and C. subiratus were known (Ardila-Camacho \& García-García, 2012), herein we reported the occurrence of $C$. surinamensis for the first time in the country.

\section{Cordulecerus praecellens (Gerstaecker, 1885) (Fig. 10)}

Ulula praecellens Gerstaecker, 1885 [1884]: 3. Holotype female. Type locality: Panama: Chiriquí (EMAU).
Specimens examined: Colombia: Tolima: Icononzo, Cafrerías, 19-VII-2014, D. Gómez (1 o'-CAUD); Valle del Cauca: bajo Anchicayá, 400 m, 23-X-1987, Light trap, (1 o'-MUSENUV); mismos datos, III-1983, R. Astroza, (1 ơ-MUSENUV); Valle, Yumbo, Dapa, 600 m, N. Márquez, on vegetation, (1 \&-MUSENUV); Darién, Reserva Nativa Yotocó [sic. Bosque de Yotoco], 1,200-1,900 m, 07-VI-1995, D. Bay, on Ziparuna (1 \&-MUSENUV).

Diagnosis: Antenna reaching laterally slightly beyond the level of forewing pterostigma, apical knob ellipsoid, dorsally white or light yellow, ventrally dark brown at base and apex, light brown on the middle. Wings are subequal in size and shape, area between CuP arch and posterior wing margin is narrower than in other species of Cordulecerus. Wing membrane infumate, sexually dimorphic, the males have membrane of both wings completely hyaline, while the females have three dark brown spots on hind wing, one between CuP and posterior wing margin at the level of RP origin, the other two are located at the distal portion of wing, with one larger and apical and one preapical and smaller and adjacent to posterior wing margin.

Remarks: Previously re-described and reported to Colombia from Cundinamarca, Quindío, and Risaralda (Ardila-Camacho \& García-García, 2012). In the present work we extended the distribution range in the coun- 
try to Valle del Cauca and Tolima (Fig. 10). This species is widely distributed in Colombia, since it can be found in the three mountainous ranges of Colombia (i.e., in the western slope of the eastern cordillera: Tolima and Cundinamarca, the western slope of the central cordillera, and in the foothills of the western cordillera of Colombia). Additionally, the species have a wide range of altitudinal distribution, ranging from 400 to $2,000 \mathrm{~m}$.

Distribution: Costa Rica, Panama, Colombia, Venezuela, and Ecuador.

\section{Cordulecerus surinamensis (Fabricius, 1798)} (Figs. 9, 10)

Ascalaphus surinamensis Fabricius, 1798: 207. Holotype, sex unknown. Type locality: Suriname (Type depository unknown).

\section{Specimens examined: Colombia: Amazonas:} Leticia, Ruta de Tarapaca, km 11, Reserva Tanimboca, 19-25-IX.2015 90 m, lat. - 04.1197, long. - 69.9523, C. Gonzalez, ligth trap (1 $\$-C A U D) ;$ Putumayo: Camino Viejo [San Francisco-Mocoa], 02-IV-2004, A. Garzón, on abaxial side of Asteraceae (1 \&-MUSENUV).

Diagnosis: Antenna reaching laterally to the level of forewing pterostigma, antennal knob ellipsoid reddish-yellow with dark brown base and apex (Fig. 9D). Head and thorax mainly black, with abundant black pubescence (Figs. 9B, C). Wings infumate, pterostigma brown composed of two or three veinlets; hind wing trianguloid, with the area between CuP and posterior wing margin at the level of RP origin with three rows of cells; area between MP and posterior wing margin at the arch of CuP level with an extensive dark brown spot (Fig. 9A).
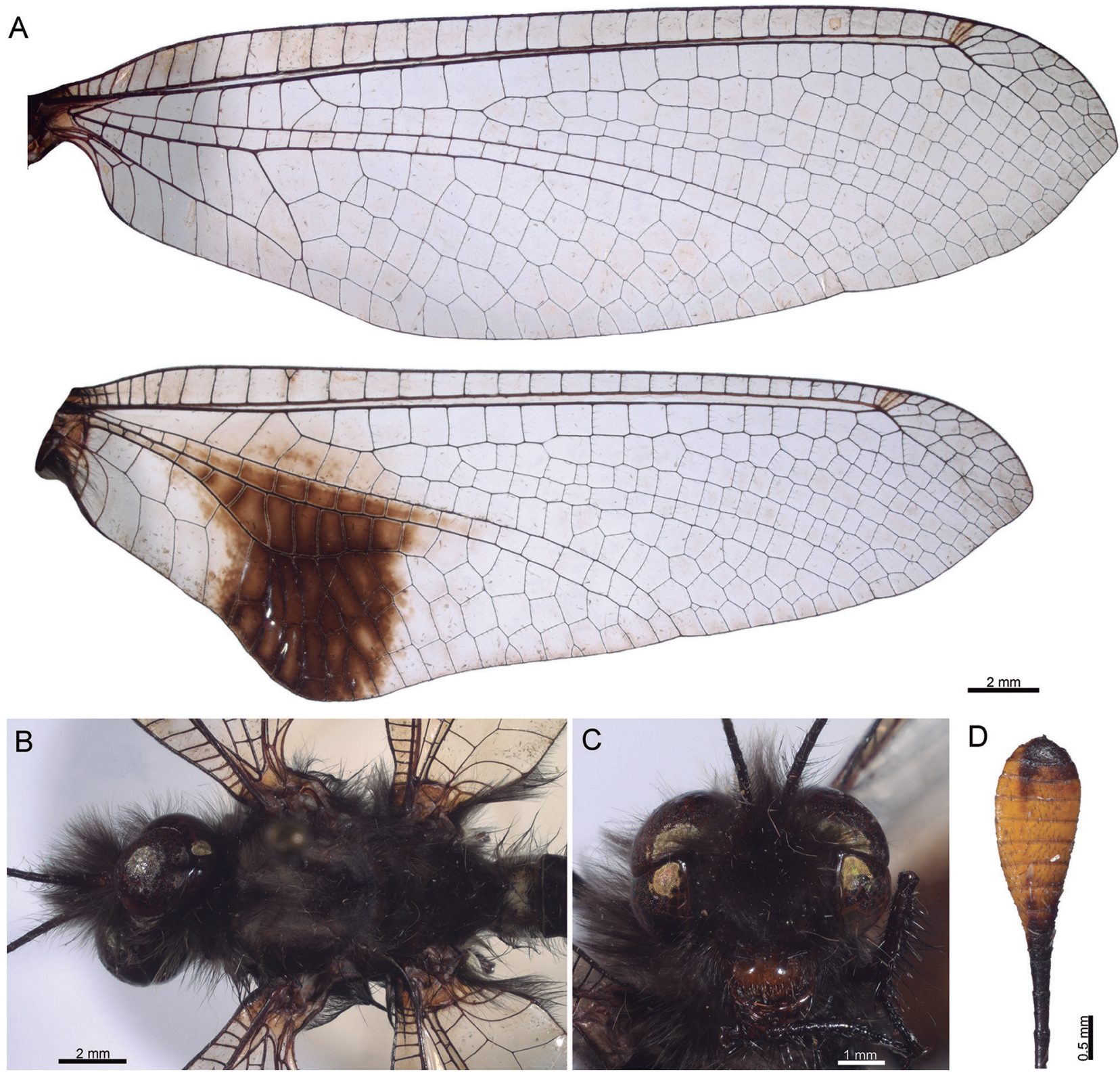

Figure 9. Cordulecerus surinamensis: (A) wing venation; (B) head and thorax, dorsal; (C) head, frontal; (D) antennal apical club. 


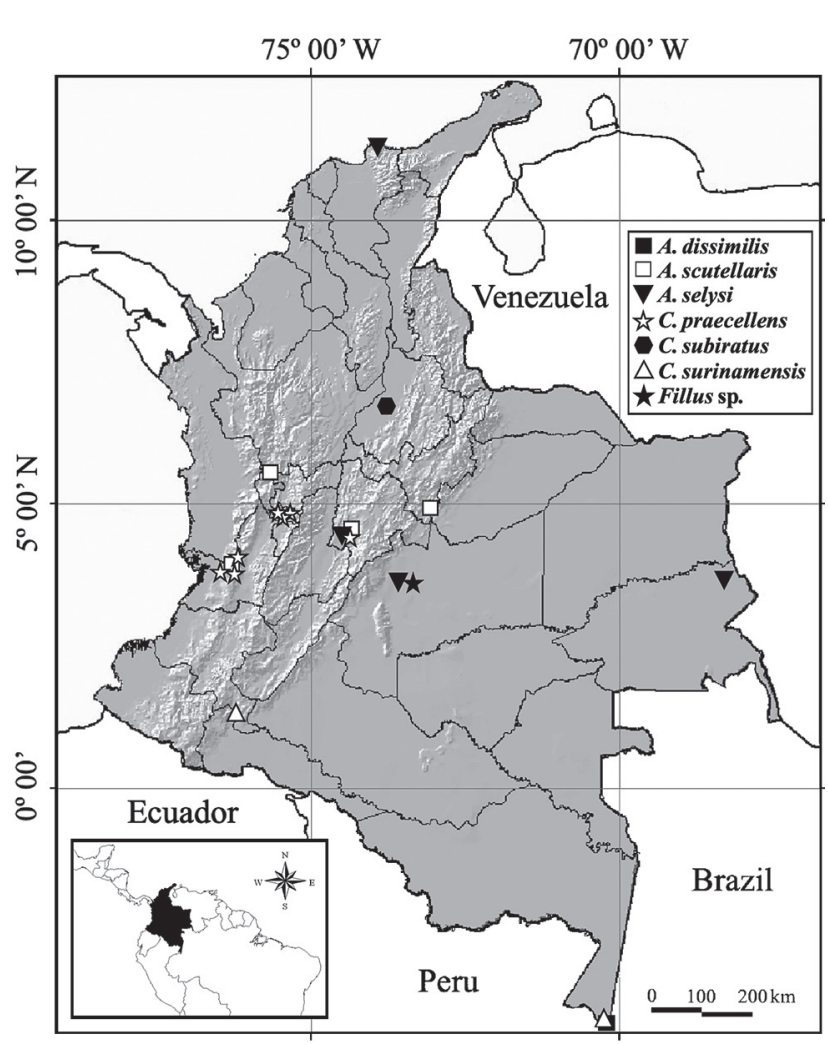

Figure 10. Collecting records of Ameropterus, Cordulecerus, and Fillus from Colombia.

Remarks: Until now, this species was known only from Brazil and Suriname (Penny, 1977). Cordulecerus surinamensis is similar to C. elegans, however the hind wing shape of this species is more pronounced, the antennae are longer with the apical knob dorsally white, thoracic nota has a wide, longitudinal, light brown stripe, and abdomen has semitriangular light brown spots surrounded with black on the tergites. Here we provide the first records of this species from Colombia, with two specimens collected in two localities of the Amazon region.

Distribution: Brazil, Colombia, and Suriname.

\section{Key to Colombian species of Cordulecerus}

1 Hind wing elongated and narrow, similar to forewing, area between arch of CuA (CuP sensu Penny, 2002) and posterior wing margin narrow; female hind wing with three amber spots adjacent to posterior margin, male without spots on hind wing (Ardila-Camacho \& GarcíaGarcía, 2012, Figs. 3a, b) .................. C. praecellens (Gerstaecker, 1884)

1' Hind wing trianguloid, area between arch of CuA (CuP sensu Penny, 2002) and posterior wing margin enlarged; hind wing membrane with different color pattern.

2 Mesonotum dark brown with paired lateral light brown stripes; hind wing basal half nearly completely brown and distal half hyaline with an apical zig-zagged mark and a preapical posterior mark (ArdilaCamacho \& García-García, 2012, Fig. 1a).... C. subiratus (Walker, 1853)

2' Mesonotum black; hind wing basal half with an extensive brown area on the enlarged area between CuA and posterior wing margin, the remainder membrane smoky (Fig. 9A)..

C. surinamensis (Fabricius, 1798)

\section{DISCUSSION}

This work represents a preliminary attempt to address a taxonomically complex group in the Neotropics. Presently, the Ululodini represent the richest group of owlflies in the Neotropics, but at the same time, it is one of the lesser studied. The generic boundaries are not so well understood, and have never been tested from a phylogenetic framework. This problem mostly underlay in the absence of comprehensive taxonomic studies. The few available revisionary works although useful, generally do not allow to identify species with reliability, making challenging the study of the group from any perspective. Additionally, several types (particularly those of Navás) were lost or destroyed. The last revisionary studies on this group in South America were made 37 years ago (Penny, 1981a, b), whilst the last complete revision of Ascalaphidae was published more than a century ago (Van der Weele, 1909). In general, these works were based on misleading characters of color patterns and venation, which result in doubtful taxonomic identifications. Yet the problem is even worse, in groups with conserved interspecific morphology, high intraspecific variation and sexual dimorphism. For example, Ululodes could be referred as the most complex taxa, in part, due to the striking similarity between their species and a considerably diversity. Penny (2002) separated Costa Rican species of this genus based on the substigmal spots and pterostigma color, however, these characters are tremendously variable and sexually dimorphic. In the case of Ameropterus, shape wing outline appears to be useful to separate the species, whereas in Cordulecerus there are very distinctive color patterns and wing morphology as occurs in other Old World genera, for example Libelloides or Deleproctophylla (Monserrat et al., 2012, 2014). To these groups the monograph of Van der Weele (1909) provides useful illustrations of the wing pattern and morphology, which help in taxonomic study on these genera. Although useful genitalia descriptions appear in the thesis of Shetlar (1977), this study was never published.

In the present paper we excluded the genus Ululodes due to the reasons exposed above, we believe that the taxonomy of this group needs to be deeply addressed using molecular and morphological approaches. In contraposition to the statements of Penny (1981b), we consider that a big proportion of the Ascalaphinae species need to be re-described and diagnosed including not only external morphology, but also genitalia descriptions, which together will help to improve the current classification of the Ascalaphinae.

\section{ACKNOWLEDGEMENTS}

We offer our sincere acknowledgments to curators of different institutions for allow us to revise the material under their care: Emilio Realpe of the Universidad de los Andes, Bogotá, Alexander García of the Universidad Distrital "Francisco José de Caldas", Bogotá, Claudia Alejandra Medina of the Instituto de Investigación en 
Recursos Biológicos Alexander Von Humboldt, Villa de Leyva, Carlos Sarmiento of the Universidad Nacional de Colombia, Bogotá, Dimitri Forero of the Pontificia Universidad Javeriana, Bogotá, and Nancy Carrejo of the Universidad del Valle, Cali. Special thanks to Rachel Diaz-Bastin of the California Academy of Sciences, Amoret Spooner of the Oxford University Museum, and Mercedes Paris of the Museo Nacional de Ciencias Naturales de Madrid for their kind help and for providing high resolution images of the specimens deposited in their respective institutions. Thanks to Daniela Lozano of the Universidad de los Andes for her friendship and support and for providing some specimens reported herein. We would like to thank to Humberto Calero Mejía of the Universidad del Valle for his hospitality during a visit to the entomological collection of his institution and to Camila Gonzales and Angela Aristizabal of the Universidad de los Andes for kindly provide specimens of the Colombian Amazonia collected during their field trips. AAC acknowledges to Consejo Nacional de Ciencia y Tecnología, Mexico CONACYT for the financial support through a doctoral scholarship and to Museum of Comparative Zoology, of the Harvard University for the funds obtained from an "Ernst Mayr Grant" award. Special thanks to Rachel Hawkins and Crystal Meier of the Museum of Comparative Zoology for their help and hospitality during a stay of the first author in the MCZ. Thanks also to Renato J.P. Machado and Joshua R. Jones for their comments and help during the development of this study.

\section{REFERENCES}

Ardila-Camacho, A. \& García-García, A. 2012. Nuevos registros y redescripción de dos especies del género Cordulecerus Rambur, 1842 (Neuroptera: Ascalaphidae) de Colombia. Boletín de la Sociedad Entomológica Aragonesa, 50: 505-511. http://sea-entomologia.org/Publicaciones/ Boletines/Boletin50/boletin50.html.

Aspöck, U. \& Aspöck, H. 2008. Phylogenetic relevance of the genital sclerites of Neuropterida (Insecta: Holometabola). Systematic Entomology, 33: 97-127.

Aspöck, U.; Plant, J.D. \& Nemeschkal, H.L. 2001. Cladistic analysis of Neuroptera and their systematic position within the Neuropterida (Insecta: Holometabola: Neuropterida: Neuroptera). Systematic Entomology, 26: 73-86.

Badano, D. \& Pantaleoni, R.A. 2014. The larvae of European Ascalaphidae (Neuroptera). Zootaxa, 3796: 287-319.

Badano, D.; Aspöck, U.; Aspöck, H. \& Cerretti, P. 2017. Phylogeny of Myrmeleontiformia based on larval morphology (Neuropterida: Neuroptera). Systematic Entomology, 42: 94-117.

Breitkreuz, L.C.W.; Winterton, S.L. \& Engel, M.S. 2017. Wing tracheation in Chrysopidae and other Neuropterida (Insecta): a resolution of the confusion about vein fusion. American Museum Novitates, 3890: 1-44. http://digitallibrary.amnh.org/handle/2246/6819.

Fabricius, J.C. 1798. Supplementum entomologiae systematicae. Hafniae. 572p. https://www.biodiversitylibrary.org/item/132638\#page/1/mode/1up.

Gerstaecker, C.E.A. 1884. Vier Decaden von Neuropteren aus der Familie Megaloptera Burm. Mitteilungen aus dem Naturwissenschaftlichen Verein für Neu-Vorpommern und Rugen, 16: 1-49.
Gerstaecker, C.E.A. 1893. Ueber neue und weniger gekannte Neuropteren aus der familie Megaloptera Burm. Mitteilungen aus dem Naturwissenschaftlichen Verein für Neu-Vorpommern und Rugen, 25: 93-173.

Heckman, C.W. 2017. Neuroptera (including Megaloptera). Encyclopedia of South American aquatic insects. Illustrated keys to the known families, genera, and species in South America. Switzerland,Springer. i-xvi, 621p.

Henry, C.S. 1976. Some aspects of the external morphology of larval owlflies (Neuroptera: Ascalaphidae), with particular reference to Ululodes and Ascaloptynx. Psyche, 83: 1-31. https://www.hindawi.com/journals/ psyche/1976/071439/abs.

Henry, C.S. 1977. The behavior and life histories of two North American ascalaphids. Annals of the Entomological Society of America, 70: 179-195.

Machado, R.J.P. \& Rafael, J.A. 2011. A new species of Fillus Navás, 1919 (Neuroptera: Ascalaphidae) from the Brazilian Amazon Basin. Zootaxa, 2907: 22-28.

Machado, R.J.P.; Gillung, J.P.; Winterton, S.L.; Garzón-Orduña I.J.; Lemmon A.R.; Lemmon, E.M. \& Oswald, J.D. 2019. Owlflies are derived antlions: anchored phylogenomics supports a new phylogeny and classification of Myrmeleontidae (Neuroptera). Systematic Entomology, 44: 418-450, 2019.

Michel, B. \& Mansell, M.W. 2018. A new genus and species of owlfly from eastern and southern Africa (Neuroptera: Ascalaphidae). European Journal of Entomology, 413: 1-12. https://europeanjournaloftaxonomy. eu/index.php/ejt/article/view/541/0.

Michel, B.; Clamens, A.-L.; Béthoux, 0;; Kergoat, G.J. \& Condamine, F.L. 2017. A first higher-level time-calibrated phylogeny of antlions (Neuroptera: Myrmeleontidae). Molecular Phylogenetics and Evolution, 107: 103-116.

McLachlan, R. 1873. An attempt towards a systematic classification of the family Ascalaphidae. Journal of the Linnean Society of London, Zoology, 11:219-276.

Monserrat, V.J.; Badano, D. \& Acevedo, F. 2014. Nuevos datos de ascaláfidos para la península Ibérica, con una nueva especie para la fauna europea (Insecta, Neuropterida, Neuroptera, Ascalaphidae). Heteropterus: Revista de Entomología, 14: 147-167. https://www.heteropterus.org/es/ HREarticulos?vid=17.

Monserrat, V.J.; Acevedo, F. \& Triviño, V. 2012. Los ascaláfidos de la Península Ibérica y Baleares (Insecta: Neuroptera: Ascalaphidae). Heteropterus: Revista de Entomología, 12: 33-58. https://www.heteropterus.org/es/ HREarticulos?vid=17.

Navás, L. 1912a. Sinopsis de los Ascaláfidos (Ins. Neur.). Arxius de I'Institut de Ciències, Institut d'Estudis Catalans, Secció de Ciències, 1: 45-143.

Navás, L. 1912b. Ascaláfidos (Ins. Neur.) sudamericanos. Brotéria Serie Zoológica, 10: 203-233.

Navás, L. 1914. Neurópteros sudamericanos. Primera [I] serie. Brotéria Serie Zoológica, 12: 45-56; 215-234.

Navás, L. 1919. Algunos insectos Neurópteros de la República Argentina. Serie tercera [III]. Revista de la Real Academia de Ciencias Exactas Físicas y Naturales de Madrid, 17: 287-305.

Navás, L. 1932. Insectos Suramericanos. Quinta Serie. Revista de la Real Academia de Ciencias Exactas, Físicas y Naturales de Madrid, 29(14): 53-66.

New, T.R. 1984. Revision of the Australian Ascalaphidae. Australian Journal of Zoology, Supplementary Series, 100: 1-86.

Oswald, J.D. 2018. Neuropterida Species of the World. Available at: http:// www.catalogueoflife.org/col/details/database/id/55.

Oswald, J.D. \& Machado, R.J.P. 2018. Biodiversity of the Neuropterida (Insecta: Neuroptera: Megaloptera, and Raphidioptera). In: Foottit, R.G. \& Adler, P.H. Insect Biodiversity: science and society. New York, John Wiley \& Sons. v. 2, p. 627-671. 
Penny, N.D. 1977. Lista de Megaloptera, Neuroptera e Raphidioptera do México, América Central, ilhas Caraíbas e América do Sul. Acta Amazonica Suplemento, 7(4): 1-61. http://www.scielo.br/scielo. php?script=sci issuetoc\&pid=0044-596719770008\&lng=pt\&nrm=iso.

Penny, N.D. 1981a. Review of the generic level classification of the New World Ascalaphidae (Neuroptera). Acta Amazonica, 11(2): 391-406. http:// www.scielo.br/pdf/aa/v11n2/1809-4392-aa-11-2-0391.pdf.

Penny, N.D. 1981b. Neuroptera of the Amazon Basin. Part 3. Ascalaphidae. Acta Amazonica, 11: 605-651. https://acta.inpa.gov.br/fasciculos/11-3/ PDF/v11n3a20.pdf.

Penny, N.D. 2002. Family Ascalaphidae. In: Penny, N.D. A Guide to the Lacewings (Neuroptera) of Costa Rica. Proceedings of the California Academy of Sciences, 53(4): 176-186; 293-299 (figs).

Rambur, J.P. 1842. Histoire naturelle des insectes, névroptères. Paris, Librairie encyclopédique de Roret. [xviii] + 534p.

Shetlar, D.J. 1977. The biosystematics of the Nearctic Ascalaphidae (Insecta: Neuropteroidea: Planipennia), with notes on biology and morphology. Ph.D. dissertation. Pennsylvania State University, University Park, Pennsylvania.

Tjeder, B. 1977. Distal abdominal segments and sclerotized parts of genitalia in Ascalaphidae (Neuroptera). Suomen Hyönteistieteellinen Aikakauskirja, 43: 61-65.

Tjeder, B. 1992. The Ascalaphidae of the Afrotropical Region (Neuroptera). 1. External morphology and bionomics of the family Ascalaphidae, and taxonomy of the subfamily Haplogleniinae including the tribes Proctolyrini $n$. tribe, Melambrotini n. tribe, Campylophlebini n. tribe, Tmesibasini n. tribe, Allocormodini n. tribe, and Ululomyiini n. tribe of Ascalaphidae. Entomologica Scandinavica, Supplement, 41: 3-169.

Tjeder, B. \& Hansson, C. 1992. The Ascalaphidae of the Afrotropical Region (Neuroptera). 2. Revision of the tribe Ascalaphini (subfam. Ascalaphinae) excluding the genus Ascalaphus Fabricius. Entomologica Scandinavica, Supplement, 41: 171-237.

Van der Weele, H.W. 1909. Ascalaphiden. Collections Zoologiques du Baron Edm. de Selys Longchamps, Catalogue Systématique et Descriptif, 8: 1-326.

Wang, Y.-y.; Liu, X.-y.; Garzón-Orduña, I.J.; Winterton, S.L.; Yan, Y.; Aspöck, U.; Aspöck, H. \& Yang, D. 2017. Mitochondrial phylogenomics illuminates the evolutionary history of Neuropterida. Cladistics, 33: 617-636.

Winterton, S.L.; Hardy, N.B. \& Wiegmann, B.M. 2010. On wings of lace: phylogeny and Bayesian divergence time estimates of Neuropterida (Insecta) based on morphological and molecular data. Systematic Entomology, 35: 349-378.

Winterton, S.L.; Lemmon, A.R.; Gillung, J.P.; Garzon, I.J.; Badano, D.; Bakkes, D.K.; Breitkreuz, L.C.V.; Engel, M.S.; Lemmon, E.M.; Liu, X.-y.; Machado, R.J.P.; Skevington, J.H. \& Oswald, J.D. 2018. Evolution of lacewings and allied orders using anchored phylogenomics (Neuroptera, Megaloptera, Raphidioptera). Systematic Entomology, 43: 330-354. 